\title{
Comparison of the Strength of Biodegradation of Pyrene between Symbiont Bacteria of Marine Sponges and Bacteria Isolated from Seawater
}

\author{
Ismail Marzuki1 ${ }^{*}$, Khairun Nisaa ${ }^{2}$, Ruzkiah Asaf ${ }^{3}$, Mudian Paena ${ }^{3}$, Admi Athirah $^{3}$, Endang Susianingsih ${ }^{3}$, Nurhi- \\ dayah Nurhidayah ${ }^{3}$, Ince Ayu Khairana Kadriah ${ }^{3}$, Kamaruddin Kamaruddin ${ }^{3}$, Sahabuddin Sahabuddin ${ }^{3}$, Nurbaya \\ Nurbaya $^{3}$, Early Septiningsih ${ }^{3}$, Herlinah Herlinah ${ }^{3}$, Erfan Andi Hendrajat ${ }^{3}$, Suwardi Suwardi ${ }^{3}$, Andi Ramlan ${ }^{4}$
}

1 Department of Chemical Engineering, Fajar University, Makassar - South Sulawesi 90231, Indonesia; ismailmz@unifa.ac.id (I.M)

2 Fishery Faculty, Cokroaminoto University of Makassar, Makassar - South Sulawesi 90245, Indonesia; nisauicha27@gmail.com (K.N)

3 Research Institute for Coastal Aquaculture and Fisheries Extension, Maros 90512, South Sulawesi, Indonesia; qiaasaf@gmail.com (R.A); mudianpaena@yahoo.co.id (M.P.); m.athirah@gmail.com (A.A.); susianingsihendang@gmail.com (E.S); nurhidayahjabir@gmail.com (N.N); inceayu@gmail.com (I.K); dgbilla@yahoo.com (K.K.); s.abud_din@yahoo.co.id (S.S); nurbayaeka@gmail.com (N.Nb); earlyseptiningsih@gmail.com (E.Sn); hjompa@yahoo.com (H.H); erfanhendrajat67@gmail.com_(E.H); suwarditahe@gmail.com (S.T).

4 Marine and Coastal Resources Management Agency of Makassar, South Sulawesi 90512, Indonesia andi.ramlan@kkp.go.id (A.R)

* Correspondence: ismailmz@unifa.ac.id (I.M)

Simple Summary: Research on environmental bioremediation is currently experiencing a positive trend. The components of PAHs are toxic and carcinogenic pollutants. Researchers widely practice the use of microorganisms in handling polluted environments. The main objective of this research was to compare the biodegradation strength between bacteria isolated from polluted seawater and microsymbionts of marine sponges. The method of bacterial biodegradation of pyrene begins with selecting bacteria that have previously been characterized by phenotype and genotype. Experiments were carried out by integrating the bacterial suspension with pyrene. The interaction period is 30 days in a $200 \mathrm{rpm}$ shaker incubator. The biodegradation parameter was determined based on the optical density at 3-day intervals, and the determination of the level of degradation was based on the abundance of pyrene using GC-MS. Analysis of functional groups of biodegradation products using FTIR. The results showed that the biodegradation level of Sb and Bl bacteria towards pyrene was relatively the same in the range of $38.00 \%-39.50 \%$ achieved within 30 days of interaction. This data can be used to protect the environment from the threat of PAHs pollutants so that the environment continues to provide optimal carrying capacity for marine ecosystems.

\begin{abstract}
PAHs contaminants have toxic, carcinogenic, and even mutagenic properties. Screening bacteria from different sources capable of carrying out the biodegradation of PAHs is important for mapping and mobilization purposes and applying them to polluted hydrocarbon environments. The study aimed to compare the biodegradation power of two types of bacteria isolated from different sources against PAHs. The method applied is the interaction between bacterial suspension and pyrene contaminated waste for 30 days. Biodegradation products in organic compounds were analyzed using GC-MS and FTIR. The analysis results found several indications of the performance of bacterial biodegradation, namely: the aggressiveness of biodegradation of Bl bacteria against pyrene was relatively more dominant than $\mathrm{Sb}$ bacteria. Percentage of total bacterial biodegradation product type $\mathrm{Sb}(39.00 \%)$, while the product of bacterial degradation type $\mathrm{Bl}(38.29 \%)$; the biodegradation products of the test bacteria ( $\mathrm{Bl}$ and $\mathrm{Sb}$ ) were relatively similar to pyrene, in the form of alcohol and carboxylic acid organic compounds. It was concluded that there was no significant difference in biodegradation performance between $\mathrm{Bl}$ and $\mathrm{Sb}$ bacteria on pyrene. Both types of bacterial isolates from different sources can carry out the function of biodegradation of Pyrene.
\end{abstract}

Keywords: biodegradation; pyrene; pollutants; bacteria; marine sponges; polluted seawater 


\section{Introduction}

Polycyclic Aromatic hydrocarbons (PAHs) are non-polar molecules. The structure is composed of carbon and hydrogen atoms, has no charge, a typical characteristic because the ring structure is capable of delocalizing electrons in the aromatic ring [1-6] PAH components in nature are naturally available, generally found in coal, petroleum, and organic materials that have undergone thermal decomposition [7-9]. Population, dynamics, and efforts to meet the needs of human life, resulting in exploration and exploitation of fossil deposits, coal, and decomposed organic biomass, being carried out more massively, resulting in the potential for disposal of PAH components in nature tends to increase from year to year [4,10-12]. Aromatic hydrocarbon chemicals consist of several types $[13,14]$. The simplest with two aromatic rings such as naphthalene, three rings (anthracene and phenanthrene), pyrene with four aromatic rings forming a stable structure and other PAHs with more rings [1,15]. PAHs generally have toxic, even carcinogenic and mutagenic properties [16-19]. The toxic level of PAH tends to increase as the structure of the aromatic ring member increases. Pyrene is one of the PAHs with a relatively high level of toxicity $[2,20,21]$. Tests on animals showed that pyrenes cause disturbances in several vital organs, especially the kidneys, liver, digestive organs, and can enter the metabolic system, while in marine ecosystems, exposure to pyrenes interferes with the growth of various types of fish, algae, seagrass, mollusk [7,22-26].

The effects caused by exposure to pyrenes and similar PAHs on marine ecosystems need to be watched out for because the sea is a giant container that provides space for almost all waste materials on earth, including several types of dangerous and toxic contaminants [9,27-30]. If this happens, then a chain effect can occur and is certain to cause problems and impact living things to target human health [8,31]. However, marine life has found materials that can reduce, degrade and deactivate the toxic properties of PAH components, especially microorganisms, such as bacteria, and fungi [5,32-34]. Deactivation of toxic aromatic elements using natural materials, such as microorganisms as biomaterials with the function of degrading aromatic components through the mechanism of destruction of the PAH aromatic ring structure by enzymatic-behaving substances produced by microorganisms, especially bacteria in response to habitats that are not conducive to life [12,35-38]

Bacteria can be found in almost all water, soil and air environments, including the sea. Bacteria in the marine can form independent communities, generally having specific characteristics and characteristics depending on their habitat [1,39-41]. Bacterial communities living in marine areas are exposed to wastes such as heavy metals, PAHs, pesticides, and biphenyl polychloride [2,42,43]. Those generally have the character and ability to adapt to these contaminants. These bacteria are predicted to have strains that can carry out the function of biodegradation and bioreduction of present contaminants. Similar to contaminants in their habitat, these bacteria can survive [6,44-46]. Several types of bacteria are part of marine biota life that can degrade hydrocarbon pollutants $[19,47]$. The mutualistic symbiosis of bacteria with sponges is a commonly found model of both lives. Sponges are marine biotas that have life dynamics as a filter feeder, often becoming objects and materials for research studies, as biomonitoring and bioindicators of pollution components of heavy metals and PAHs [21,48-50]. This situation indicates that sponges can adapt or survive in an environment exposed to PAHs and heavy metals [7,51-52]. Analysis of the life aspects of sponges, generally, sponges are always in symbiosis with microorganisms, especially bacteria, so it is interesting to conduct an in-depth study of whether there is a relationship between sponges, bacterial symbiosis and PAH contaminants [17,53-55].

Many research reports show that several types of bacteria can degrade hydrocarbon components, where bacteria can absorb carbon and convert it into energy [56,57]. Bacillus and pseudomonas bacteria are known to be able to carry out the function of biodegradation of hydrocarbon components [4,58,59]. Gram-positive bacteria, found in the form of bacilli, generally having obligate aerobic properties, and some can become anaerobic 
when oxygen is not available $[3,60,61]$. Bacillus group bacteria that live in contaminated environments can produce endospores as a form of camouflage and can survive for a long time. Bacteria of the Bacillus group often symbiosis with marine sponges [62]. Sphingobacterium group of bacteria is a genus that belongs to the Sphingobacteriaceae family, containing high concentrations of sphingophospholipids $[11,63]$. Sphingobacterium is a group of bacteria isolated from several habitat sources, one of which can be obtained from seawater [64]. Both groups of bacteria can biodegrade aromatic hydrocarbon components. The main objective of this research is the availability of quantitative data related to the biodegradation strength of a type of bacteria obtained from different sources $[65,66]$.

Bioremediation of PAHs using microorganisms has been widely developed. Several types of bacteria capable of carrying out the function of biodegradation of PAHs that have been isolated from seawater are suspected to be contaminated with hydrocarbons, including Bacillus [67], Gammaproteobacteria, Pseudomonadales [4,68]. Isolates from hydrocarbon contaminated soil, Micrococcus luteus [34], Lasiodiplodia theobromae [36], Pseudomonas aeruginosa [69]. Several bacteria were isolated from marine biota, especially marine sponge microsymbionts, for example, Bacillus Sp strain AB353f, B. pumilus strains GLB197, B. cohnii strains of DSM 6307 and Acinetobacter Calcoaceticus strain PHCDB14 $[9,21,70]$. Microorganisms associated with mangroves have also been identified to carry out the biodegradation function of PAHs [40,70,71]. Other research on the biodegradation of hydrocarbon components using Ganoderma lucidum, Penicillium sp, filamentous diisolasi dari fungi $[3,7,32,60,72]$. Types of PAHs that have been successfully degraded by a number of microorganisms including bacteria and fungi), such as naphthalene [8,21,38], anthracene [4,10,73], phenanthrene [7,50], pyrene [2,7,40,74], Benzo[a]pyrene [36,37].

Comparative analysis of the strength of bacterial biodegradation of PAH components is important to map the type, source and effectiveness of the biodegradation of these bacteria against PAHs [75,76]. The data from this research can also be used as a reference for developing and applying environmental bioremediation against other types of pollutants, such as heavy metals, microplastics, and pesticide residues. The potential for future bioremediation using bacteria is very likely to occur in treating medical waste, radioactive and other hazardous chemicals [6,77-79]. The use of bacteria that have remediation capabilities is also potentially applied to liquid waste, solid waste environments, and even air. The development of knowledge on screening the type and source of bacteria is interesting, especially for microorganisms such as fungi [44,57,61].

Research on the biodegradation of pollutants in the environment using microorganisms such as bacteria and fungi is still very wide open. It is an interesting research area, including its benefits in the future, to produce new findings in the context of environmental management [80,81]. This research is one of the series and developments of several previous studies carried out on carcinogenic PAHs in the theme of screening for hydrocarbon-degrading bacteria [12,82]. The novelty presented in this research is the source of bacteria isolated from marine sponges for the application of biodegradation of PAHs [83]. The biodegradation method of hydrocarbon components was previously carried out generally using microorganisms, both bacteria and fungi, mostly isolated from liquid waste, solid waste, and polluted industrial waste [84,85].

In the future, it is our dream to develop a formulation containing a crystalline collection of bacteria that has high ability and performance in degrading various pollutants, especially PAHs [86]. We call this group of crystalline bacteria the hydrocarbonoclastic bacteria. Hydrocarbonoclastic crystalline bacterial formulas are arranged to be quickly mobilized and applied to locations or areas contaminated with hydrocarbon components $[3,87]$. We have carried out a series of intensive research to reach the peak of research, which is the long-term goal of this program. 


\section{Materials and Methods}

\subsection{Materials}

The main ingredients used in this study were bacterial isolates of Bacillus licheniformis strain ATCC 9789 (Bl), bacteria isolated from the marine sponge Auletta sp., and bacterial isolates of Sphingobacterium sp. strain $21(\mathrm{Sb})$, bacteria isolated from seawater suspected to be contaminated hydrocarbon components [11,85,88]. The basis for selecting these two types of bacteria was following the results of phenotypic characterization using the 16-parameter biochemical test method and isolate genotypic analysis using PCR with the universal primer sequence pair of the 16S rRNA for E. coli gene: FPU1 (5'-CCA....ACG-3') at 518 nucleotides. -537 , and RP-U2 at (5'ATCGG (C/T)TAC.....TTC-3') corresponding to nucleotides 1513-1491, DNA template, Taq DNA polymerase $[85,89,90]$. Other materials are pyrene (sigma), N-hexane (brand) for GC, anhydrous $\mathrm{Na}_{2} \mathrm{SO}_{4}$, PA, alcohol, peptone, glucose, nutrient agar, physiological $\mathrm{NaCl}$ $0.9 \%$, yeast extract, aquabides, spiritus and nitrogen gas.

\subsection{Sampling}

The location and sampling point of the bacterial source is as shown in Figure 1.
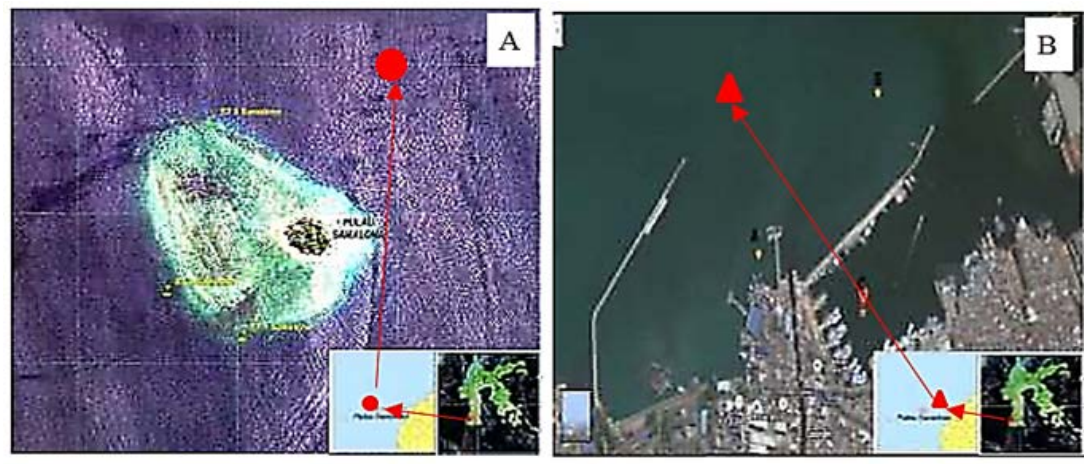

Figure 1. Sampling locations of sea sponges and seawater sources of bacterial isolates. The distance between the two sampling points is $\pm 3.45 \mathrm{Nm}$, (A) Map of Kodingareng Keke Island, part of the Spermonde Archipelago Cluster, Makassar City Administration. The sampling location of the marine sponge Auletta sp., the source of Bl. Sponge sampling point (red circle) at coordinates $S$ 506'38.12'76"; E 119¹7'7.76'44"; (B) Sampling location of seawater source of bacteria type Sb (red triangle), obtained around Soekarno-Hatta Seaport, Makassar. The seawater sampling point is at coordinates S 506'25.23'14"; E 119²5'3,21.25".

\subsection{Sample Preparation}

The candidates for biodegradation bacteria were selected, namely Bacillus licheniformis strain ATCC $9789(\mathrm{Bl})$ and Sphingobacterium sp. strain $21(\mathrm{Sb})$. In the first stage, bacterial isolate cells were propagated by the culture method. The culture was carried out in a test tube, and then the bacterial cells were suspended using aquabides. Incubated for $1 \times 24$ hours and carried out a Gram staining test to confirm the gram groups of the two types of bacteria tested. Prepare a row of sterilized labelled degradation vials. Each vial was filled with $10 \mathrm{~mL}$ of bacterial suspension, then adapted to the new environment for 1 x 24 hours in an incubator. In the second stage, $200 \mathrm{~mL}$ of pyrene $1000 \mathrm{mg} / \mathrm{L}$ was made $[6,9,21]$. In each degradation vial that already contains a bacterial suspension, $5 \mathrm{~mL}$ of pyrene solution is added so that the interaction between the bacterial suspension and the pyrene solution occurs. Each degradation vial was placed in a shaker incubator and agitated at $200 \mathrm{rpm}$. The contact between the bacterial suspension and pyrene (substrate) lasted for 30 days. Every 3 days, biodegradation parameters (optical density) were observed and measured. Measurement of the level of biodegradation was carried out after the interaction of 10, 20 and 30 days using GC-MS [19,23,29]. All samples in the vial that had reached an interaction period of 10 days and their multiples were extracted using $\mathrm{N}$-hexane to extract the pyrene component that was not degraded. The types of biodeg- 
radation products in simple organic compounds were analyzed based on the functional groups shown on the FTIR chromatogram $[14,68,91]$. The percentage of biodegradation rate and the concentration of non-degradable pyrene was determined using equations 1 and $2 \quad[4,15,33]$

Conc. Of degr.comp. $X(\%)=\frac{(\text { initial conc.of comp. } X)-(\text { final conc.of conp.X })}{(\text { Total conc.of comp. })} \times 100 \%$,

Cerc. Of comp. biodegr. Products $(\%)=\frac{\text { Total comp.of biodegr.products }}{\text { Tatal conc.of comp. }} \times 100 \%$,

\section{Results}

\subsection{Microscopic and morphological analysis}

The culturing process of two isolates used as PAH degradators were selected from different sources. Bacillus licheniformis strain ATCC 9789 (Bl) was a bacterium isolated from the marine sponge Auletta sp., while Sphingobacterium sp. strain $21(\mathrm{Sb})$ was isolated from seawater suspected of being exposed to PAHs. The two test bacteria were selected based on the biodegradation potential of their PAHs by previous studies [3,5,92]. The process of culturing, morphology and microscopy of the two types of isolates used to degrade PAHs, especially pyrene, respectively, is as shown in Figures 2, 3 and 4.
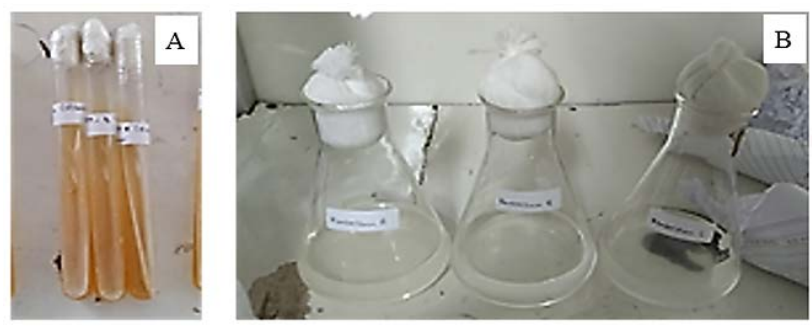

Figure 2. PAHs-degrading isolate culture process; (A) Isolate $\mathrm{Bl}$ and $\mathrm{Sb}$ on nutrient agar slant; (B) Preparation of bacterial suspension.
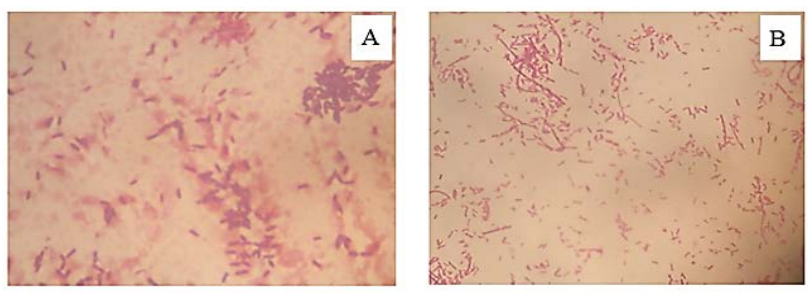

Figure 3. Results of microscopic analysis of 2 types of bacteria by Gram staining; (A) Bacterial isolate Bacillus licheniformis strain ATCC 9789 (Bl) is a group of Gram-positive bacteria; (B) isolates of Sphingobacterium sp. is a group of Gram-negative bacteria ( $\mathrm{Sb})$.
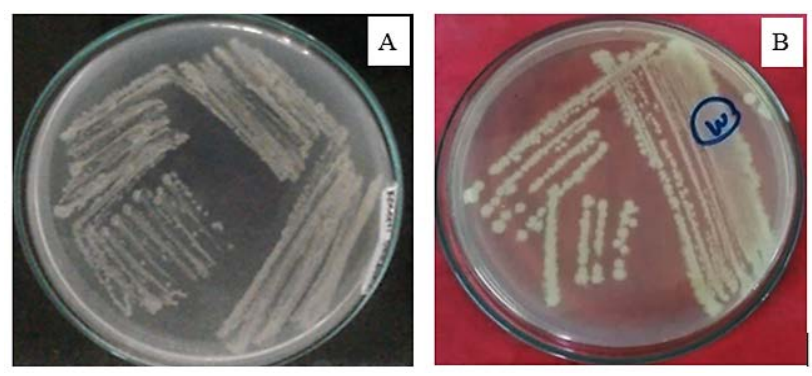

Figure 4. Comparison of the morphology of PAH biodegradator bacterial isolates (pyrene) after $1 \mathrm{x}$ 24 hours incubation; (A) Growth of Bl type bacterial isolates; (B) growth of Sb type bacterial isolates. 
According to the criteria for phenotypic and genotypic characteristics, isolates $\mathrm{Bl}$ and $\mathrm{Sb}$ were selected (Fig. 2A). Both isolates were cultured, and the culture results were converted into suspension (Fig. 2B). The microscopic analysis results show that isolate Bl (Fig. 3A), isolated from marine sponge type Auletta Sp., where the sponge was obtained around Kodingareng Keke Island (Fig. 1A), is a group of Gram-positive bacteria. In contrast, isolate Sb (Fig. 3B) is isolated from seawater, which is strongly suspected of contamination with hydrocarbon components. Seawater source of Sb isolates was obtained around the Soekarno Hatta Port area, Makassar City (Fig. 1B). Sb bacteria are a group of Gram-negative bacteria [30,50,93].

The morphology of bacterial isolate $\mathrm{Bl}$ (Fig. 4A) can be illustrated as follows: ridged rod shape, cream colour, spread in clusters, have endospores, but less clear, while bacterial isolate $\mathrm{Sb}$ (Fig. 4B), ridged rod shape, brown colour, different distribution, lack an endospore $[41,50]$. These two types of bacteria have striking differences, not only on the source of isolates but also on different types, strains or characters, Gram groups, including different morphological and microscopic isolates. Thus it is suspected that there are differences in the degradation ability of PAH components, especially pyrene [39]. Comparison of growth rates between $\mathrm{Bl}$ and $\mathrm{Sb}$ bacteria on selective media with an incubation period of up to 30 days can be seen based on the optical density of the growth of the two types of bacteria measured at $\lambda$ maks $600 \mathrm{~nm}[3,9]$, according to Figure 5.

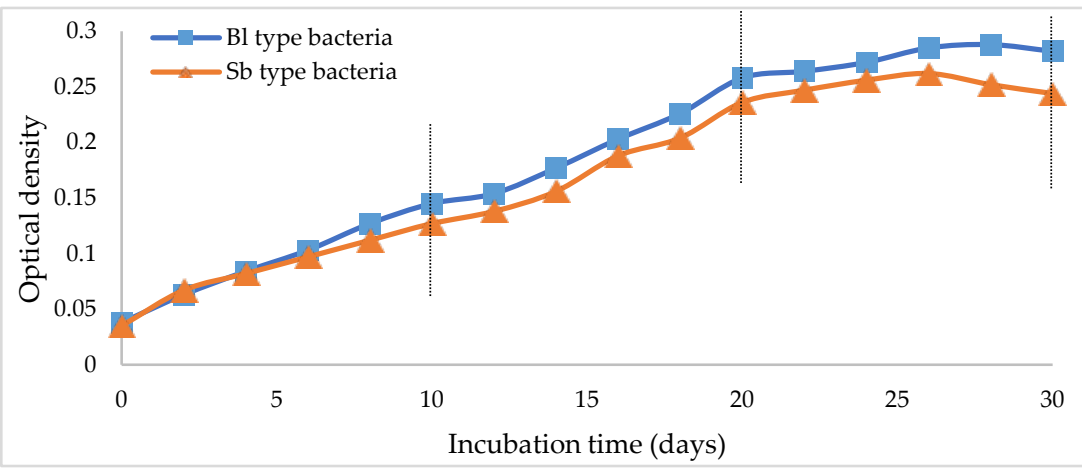

Figure $5 . \mathrm{Bl}$ and $\mathrm{Sb}$ bacterial cell growth curves on selective media without the addition of pyrene contaminants

Based on the optical density (Fig. 5), it was shown that Bl bacteria had a higher optical density than Sb bacteria. This situation indicates that the population and cell size of $\mathrm{Bl}$ bacteria is large, growth is more aggressive than Sb bacteria. Changes in optical density according to the incubation period, it can also be assumed that the growth rate of $\mathrm{Bl}$ bacteria is higher than that of Sb bacteria. So it can be predicted that the level and strength of degradation of $\mathrm{Bl}$ bacteria are dominant compared to Sb bacteria. In the incubation period for the first ten days, both bacteria appear in the adaptation phase. The next ten days or an incubation period of 20 days shows the bacteria in the cell division or multiplication phase. The incubation period for 30 days shows that bacterial cells have decreased activity. The optical density value of $\mathrm{Bl}$ bacteria was higher than that of $\mathrm{Sb}$ bacteria (Fig. 5), indicating that Bl bacteria had higher growth activity than Sb bacteria. This condition can be used as a measure to predict that these two types of bacteria have different biodegradation strengths against PAH components, especially pyrene $[1,7,14,37]$

Comparison of the optical density (OD) values of the two types of bacteria during the interaction with pyrene can be assumed to embody the biodegradation power of $\mathrm{Bl}$ and $\mathrm{Sb}$ bacteria against pyrene (Fig. 6). It appears that the OD of Bl bacteria is higher than that of $\mathrm{Sb}$ bacteria. The difference in $\mathrm{OD}$ values begins to be seen at the 6-day interaction period, where the OD shown in the interaction of bacteria $(\mathrm{Bl}+$ pyrene) is higher than the $\mathrm{OD}$ value of the interaction of bacteria $(\mathrm{Sb}+$ pyrene). This situation continues until the 
interaction reaches 30 days; even the difference in $\mathrm{OD}$ values tends to get wider with increasing interaction time. This indicator shows that the biodegradation activity of $\mathrm{Bl}$ bacteria against pyrene is more potent than that of $\mathrm{Sb}$ bacteria. In general, it can be said that both types of test bacteria have degradation activity against pyrene $[30,73]$

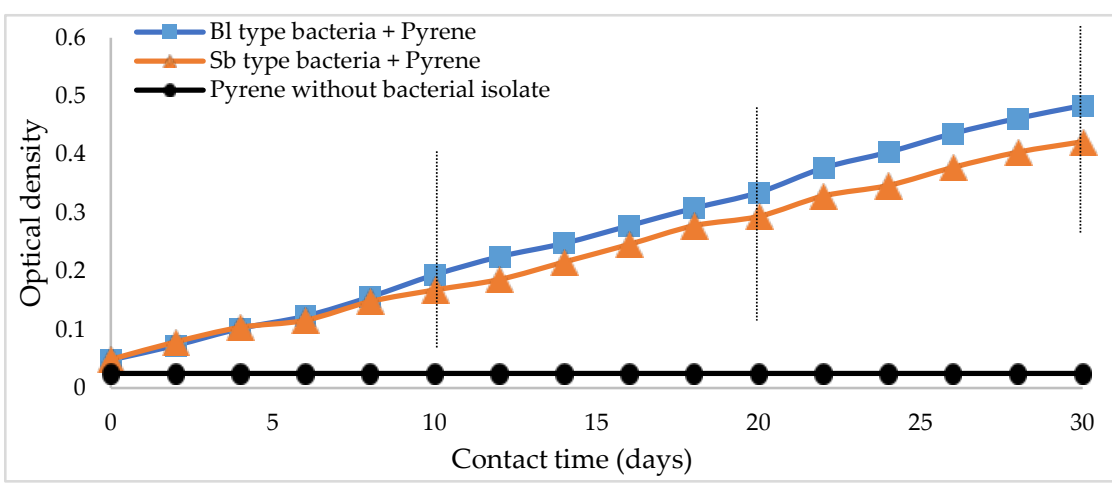

Figure 6. Bacterial cell growth curves $\mathrm{Bl}$ and $\mathrm{Sb}$ on selective media with pyrene contaminants.

Another indicator that shows that pyrene is degraded by $\mathrm{Bl}$ and $\mathrm{Sb}$ test bacteria by looking at several degradation parameters. Including (1) increasing the temperature at the interval of $28^{\circ} \mathrm{C}-30^{\circ} \mathrm{C}$, during the interaction period $(10-24)$ days, and decreasing to $29^{\circ} \mathrm{C}$, during the interaction period $(26-30)$ days; (2) there is a change in the $\mathrm{pH}$ of the interaction medium at $\mathrm{pH} 6.64$ which gradually decreases to $\mathrm{pH}$ 5.34, (the interaction medium is slightly more acidic). This condition occurs during the 8 to 30 day interaction period $[24,33]$; (3) it was observed that gas bubbles in the interaction medium were seen on the 8th day of contact, and the population tended to increase with increasing interaction time; and (4) the smell of fermentation from the interaction medium, observed on the 10th day of interaction until the 30th day of the measurement period. However, it is said that these four points of biodegradation parameters cannot distinguish the strength of the biodegradation activity between $\mathrm{Bl}$ and $\mathrm{Sb}$ bacteria on pyrene biodegradation $[2,27,35]$. The biodegradation parameters are qualitative data. The difference in the strength of biodegradation between $\mathrm{Bl}$ and $\mathrm{Sb}$ bacteria against pyrene can be predicted through the OD value (Fig. 6), A higher OD value indicates that the growth and development process of $\mathrm{Bl}$ bacteria is more dominant than $\mathrm{Sb}$ bacteria in the interaction between bacteria and pyrene $[8,37,74]$.

\subsection{Comparison of the biodegradation performance of test bacteria}

Analysis of the difference in the strength of the biodegradation of the two bacteria tested against pyrene, based on aspects of the abundance of components and the number of peaks formed (Fig. 7 -9), types and differences in organic compounds of degradation products (Table 1-2).
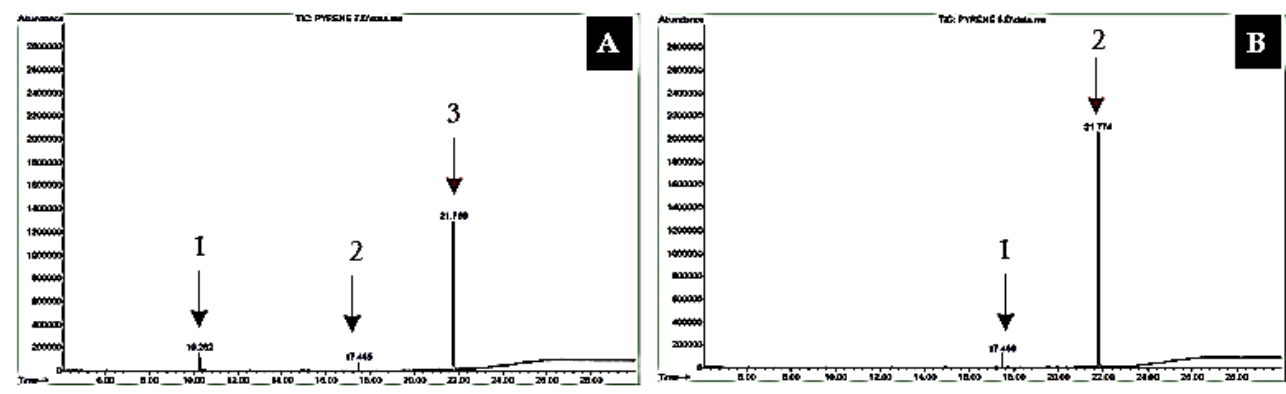

Figure 7. Comparison of peak abundances of biodegradation chromatograms, interaction time of 10 days; (A) Chromatogram of degradation between bacterial isolate $\mathrm{Bl}$ and pyrene; (B) Chromatogram of degradation between bacterial isolates of $\mathrm{Sb}$ and pyrene 
The difference percentage of pyrene that did not undergo biodegradation and the components organic compounds of biodegradation products (Fig. 10-11). It includes functional groups of organic compounds of biodegradation products (Fig. 12 - 13). These three indicators provide qualitative and quantitative data on the strength of the biodegradation of the two types of bacteria against pyrene $[40,48,61]$
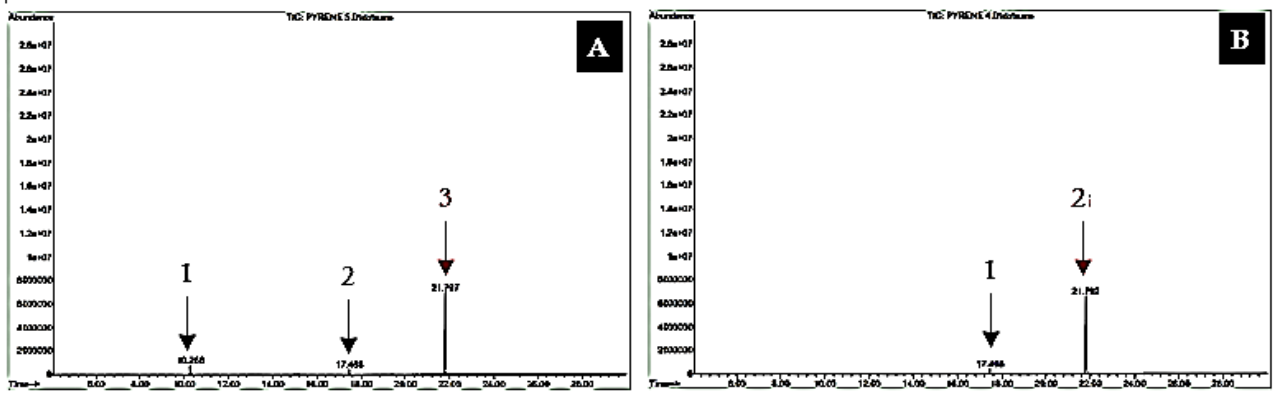

Figure 8. Comparison of peak abundances of biodegradation chromatograms, interaction time 20 days; (A) Chromatogram of degradation between bacterial isolate $\mathrm{Bl}$ and pyrene (B) Chromatogram of degradation between bacterial isolate $\mathrm{Sb}$ and pyrene.
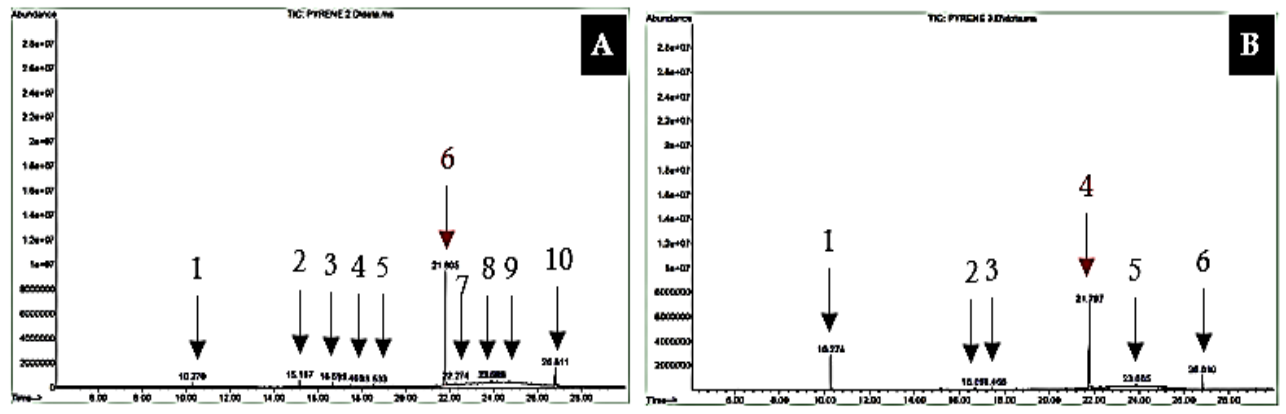

Figure 9. Comparison of peak abundances of biodegradation chromatograms, interaction time 30 days; (A) chromatogram of degradation between bacterial isolate $\mathrm{Bl}$ and pyrene (B) Chromatogram of degradation between bacterial isolate $\mathrm{Sb}$ and pyrene.

Based on a comparison of GC-MS chromatograms at 10-day contact of biodegradation of pyrene components, there were three peaks (Fig. 7A) resulting from the interaction of $\mathrm{Bl}$ bacteria with pyrene, there were two peaks (Fig. 7B) interactions between $\mathrm{Sb}$ bacteria and pyrene, indicating that B1 bacteria had the reducing aggressiveness of pyrene was more potent than that of Sb bacteria. The GC-MS chromatogram at the 20-day interaction period between $\mathrm{Bl}$ and $\mathrm{Sb}$ bacteria against pyrene (Fig. 8A, 8B), showed a relatively similar appearance to the 10-day interaction, especially the number of peaks. However, the peak height indicating the pyrene component decreased more sharply than in During the first ten days of interaction, on the other hand, the components suspected of being biodegradation products experienced a slight increase in peak height, indicating an increase in the components of degradation products [38]. Chromatograms for the 30-day interaction between $\mathrm{Bl}$ and $\mathrm{Sb}$ bacteria on pyrene (Fig. 9A, 9B), experienced significant changes, especially in the number of new peaks formed, indicating the biodegradation product component the peak height of the pyrene component experienced a sharp decrease. The chromatogram of the interaction of $\mathrm{Bl}$ bacteria with pyrene identified ten peaks (Fig. 9A), indicating that there were nine components of the bacterial biodegradation product type $\mathrm{Bl}$.

In contrast, in the interaction of bacteria Sb with pyrene (Fig. 9B), only six peaks were seen, indicating five peaks identified with the component the product of bacterial biodegradation of Sb. Numbers and arrows in red (Fig. 7-9) indicate the pyrene component as a substrate that undergoes degradation $[7,40,74]$. These results showed that 
Bl-type bacteria isolated from the marine sponge Auletta sp. had more aggressive biodegradation activity and dynamics against pyrene than $\mathrm{Sb}$ type bacteria isolated from PAH-contaminated seawater $[36,41]$. The biodegradation dynamics of the two types of bacteria tested against pyrene are shown in Tables 1 and 2.

Table 1. Data on readings of GC-MC biodegradation between biodegradator bacteria Bacillus licheniformis strain ATCC 9789 (Bl) against pyrene

\begin{tabular}{|c|c|c|c|c|c|c|}
\hline $\begin{array}{l}\text { Peak } \\
\text { number }\end{array}$ & $\begin{array}{c}\text { Retention } \\
\text { Time } \\
\text { (Seconds) }\end{array}$ & Height peak & Area $(\%)$ & $\begin{array}{c}\text { Total Conc. } \\
(\%)\end{array}$ & $\begin{array}{l}\text { Quality } \\
\text { (\%) }\end{array}$ & Compounds name \\
\hline \multicolumn{7}{|c|}{ Contact time 10 days } \\
\hline 1 & 10.261 & 156964 & 8,99 & 8,99 & 94 & Naphthalene \\
\hline 2 & 17.467 & 4366 & 3,90 & 3,90 & 45 & Meso-4,5-Dicyclohexyl-2 \\
\hline 3 & 21.771 & 4282463 & 87,11 & 87,11 & 95 & Pyrene \\
\hline \multicolumn{7}{|c|}{ Contact time 20 days } \\
\hline 1 & 10.267 & 730588 & 13,26 & 13,26 & 94 & Naphthalene \\
\hline 2 & 17.467 & 427236 & 3,88 & 3,88 & 50 & 3-dimethyl-methanephosphonate \\
\hline 3 & 21.796 & 3809710 & 82,87 & 82,87 & 96 & Pyrene \\
\hline \multicolumn{7}{|c|}{ Contact time 30 days } \\
\hline 1 & 10.273 & 454990 & 4,29 & 4,29 & 94 & Naphthalene \\
\hline 2 & 15.165 & 551463 & 3,95 & 3,95 & 98 & $\begin{array}{c}\text { Phenol, } \\
\text { 2,6-bis(1,1-dimethylethyl) }\end{array}$ \\
\hline 3 & 16.697 & 420591 & 3,77 & 3,77 & 97 & Benzenemethanol \\
\hline 4 & 17.467 & 282380 & 2,49 & 2,49 & 50 & Oxalic acid \\
\hline 5 & 18.530 & 247395 & 2,95 & 2,95 & 95 & Phenanthrene \\
\hline 6 & 21.808 & 1199647 & 61,71 & 61,71 & 96 & pyrene \\
\hline 7 & 22.271 & 277763 & 2,68 & 2,68 & 95 & 1-Nonadecene \\
\hline 8 & 23.885 & 208195 & 2,65 & 2,65 & 93 & Eicosane \\
\hline 9 & 23.947 & 222869 & 3,60 & 3,60 & 95 & Tetrapentacontane \\
\hline 10 & 26.812 & 1507974 & 11,90 & 11,90 & 87 & Terephthalic acid \\
\hline
\end{tabular}

Note: Peak number according to GC-MS chromatogram (Fig. 7 - 9) section A.

Table 2. Data on readings of GC-MC biodegradation results between biodegradator bacteria Sphingobacterium sp. strain $21(\mathrm{Sb})$ against pyrene

\begin{tabular}{|c|c|c|c|c|c|c|}
\hline $\begin{array}{c}\text { Peak } \\
\text { number }\end{array}$ & $\begin{array}{c}\text { Retention } \\
\text { Time } \\
\text { (Seconds) }\end{array}$ & $\begin{array}{c}\text { Height } \\
\text { peak }\end{array}$ & Area $(\%)$ & $\begin{array}{c}\text { Total Conc. } \\
(\%)\end{array}$ & $\begin{array}{c}\text { Quality } \\
(\%)\end{array}$ & Compounds name \\
\hline \multicolumn{7}{|c|}{ Contact time 10 days } \\
\hline 1 & 17.467 & 127964 & 4,95 & 4,95 & 52 & 1,3-dimethylbutyl phosphonate \\
\hline 2 & 21.777 & 4010224 & 95,05 & 95,05 & 96 & Pyrene \\
\hline \multicolumn{7}{|c|}{ Contact time 20 days } \\
\hline 1 & 17.467 & 407716 & 16,16 & 16,16 & 52 & 2H-Tetrazole \\
\hline 2 & 21.789 & 3481296 & 83,84 & 83,84 & 95 & Pyrene \\
\hline \multicolumn{7}{|c|}{ Contact time 30 days } \\
\hline 1 & 10.273 & 2826324 & 23,21 & 23,21 & 94 & Azulene \\
\hline 2 & 16.698 & 261361 & 2,46 & 2,46 & 97 & Benzenemethanol \\
\hline 3 & 17.467 & 263235 & 1,72 & 1,72 & 52 & 2H-Tetrazole \\
\hline 4 & 21.796 & 2788232 & 61,00 & 61,00 & 96 & Pyrene \\
\hline 5 & 23.883 & 229305 & 1,59 & 1,59 & 58 & Tricosane \\
\hline 6 & 26.812 & 1144755 & 10,03 & 10,03 & 87 & Terephthalic acid \\
\hline
\end{tabular}

Note: Peak number according to GC-MS chromatogram (Fig. 7 - 9) section B.

The results of the biodegradation of B1 bacteria against pyrene were by the results of the GC-MS readings (Table 1). Several benchmarks indicate that there has been biodegradation of pyrene as a substrate by type $\mathrm{Bl}$ biodegradator bacteria, including: first, the decrease in the peak height of the pyrene component, which is analogous to the decrease in pyrene concentration due to changes in structure, decomposition, degradation or reduction of components, as a result of bacterial activity type Bl. Second, the decrease in the percentage area of the pyrene component is a sign that the concentration of pyrene is 
getting smaller as the interaction time between Bl bacteria and pyrene increases. Third, the percentage of the total composition of the biodegradation product increased with increasing contact time between Bl bacteria and pyrene. Furthermore fourth, the number of components formed tends to increase following the increase in interaction time. However, the number of these components is not entirely seen as the end product of degradation. This product can be seen from the percentage value of quality; if it does not reach $90 \%$ and above (Table 1), then it cannot be categorized as the final product of bacterial biodegradation because perhaps the component is a transition product $[19,62,66]$

The analysis of the biodegradation process for $\mathrm{Bl}$ bacteria against pyrene, according to the GC-MS reading data (Table 1), was relatively identical to the biodegradation data for $\mathrm{Sb}$ bacteria against pyrene (Table 2). Comparative analysis of the biodegradation strength between Bacillus licheniformis strain ATCC 9789 (Bl) and pyrene based on interaction time showed that the symbiont bacteria of the marine sponge Auletta sp. The biodegradation power is relatively balanced compared to Sphingobacterium sp. strain 21 (Sb) isolated from seawater contaminated with PAHs. However, it does not necessarily mean that marine sponge symbiont bacteria have weaker biodegradability against PAH components than bacteria isolated from seawater contaminated with hydrocarbon component pollutants $[15,18]$. General conclusions regarding the biodegradation strength of marine sponge symbiont bacteria compared to bacterial isolates from seawater contaminated with PAHs require a comprehensive bacterial investigation and analysis $[48,71]$

\subsection{Tingkat biodegradasi}

Comparative analysis of the biodegradation strength between $\mathrm{Bl}$ and $\mathrm{Sb}$ bacteria against pyrenes based on interaction time (Fig. 10), in general, it can be seen in the total pyrene that was not degraded by the test bacteria.

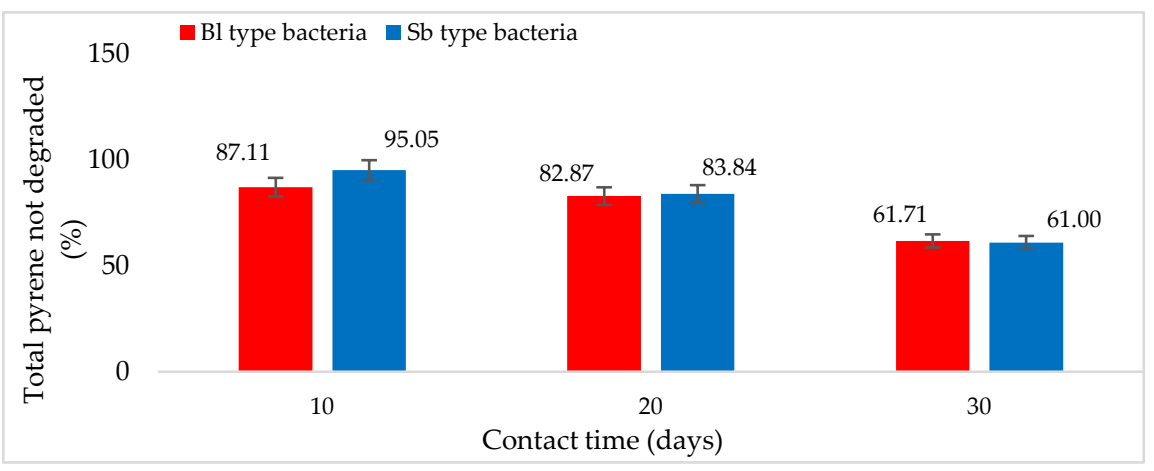

Figure 10. Comparison of the percentage of pyrene components as a substrate not degraded by $\mathrm{Bl}$ and $\mathrm{Sb}$ bacteria based on interaction time.

The results of the analysis of the biodegradation activity of the tested bacteria on the pyrene component showed no significant difference in the strength of the biodegradation. However, there were differences in the total degraded pyrene component at several times of observation and measurement. The dominance of the biodegradation power of B1 bacteria against pyrene was seen in the contact phase for the first ten days. In the second 10-day contact phase, it appears that the biodegradation strength of the two types of bacteria tested is relatively balanced. 


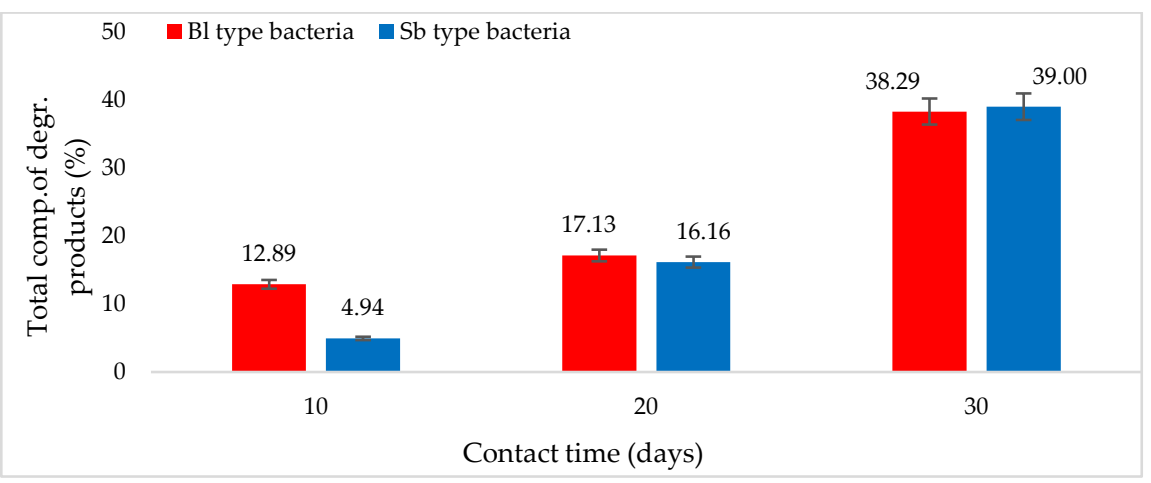

Figure 11. Comparison of the percentage of the total components of bacterial biodegradation products of $\mathrm{Bl}$ and $\mathrm{Sb}$ types to pyrene based on interaction time

Even in the third 10-day contact phase, the biodegradation strength of Sb bacteria appears to outperform Bl type bacteria (Fig. 10). These results have implications for the total biodegradation products predicted to follow a relatively undifferentiated pattern.

Aspects of the percentage analysis of the total components of the biodegradation product as a result of the work of the two types of bacteria tested against pyrene (Fig. 11), showed a similarity in the path of biodegradation strength. The percentage of total biodegradation products of $\mathrm{Bl}$ test bacteria in the first ten days of contact phase was greater than that of Sb's total biodegradation products. However, in the second 10 days of contact, the per cent of total biodegradation products between the two test bacteria showed almost similar results. Even at the third phase of contact, the 30th day of the interaction period, the percentage of total biodegradation products of $\mathrm{Sb}$ type bacteria was more significant than $\mathrm{Bl}$ type bacteria $[5,11,94]$.

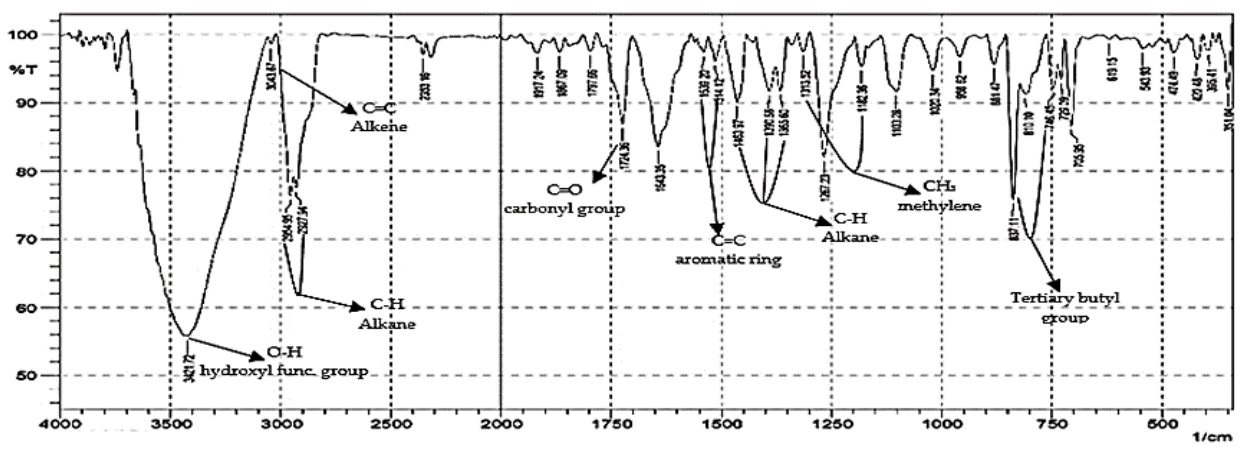

Figure 12. FTIR spectrum showing functional groups of organic components in the biodegradation performance of Bacillus licheniformis strain ATCC 9789 (Bl) against pyrene after 30 days of interaction

An overview of the energy aspects of most molecular vibrations relates to the infrared region. Molecular vibrations can be detected and measured in the infrared spectrum. The results of the FTIR spectra analysis showed that after the interaction between the pyrene component and the suspension of the test bacteria, the pyrene component decomposed into simple organic compounds, it could be analyzed based on the wavenumbers of the functional groups according to the FTIR chromatogram shown by the Bl and $\mathrm{Sb}$ test bacteria $[6,12,68,95]$.

The results of FTIR analysis (Fig. 12), showed that one of the degradation products of simple organic compounds, in the form of phenol, alcohol monomer, hydrogen-bonded alcohol, carboxylic acid group, carboxylic acid hydrogen bond, and aromatic carbon-hydrogen bond. Absorption in the range 3200-3600 $\mathrm{cm}^{-1}$, range $3444,87 \mathrm{~cm}^{-1}$, indicates the presence of the -OH functional group. Absorption $2958.80 \mathrm{~cm}^{-1}$ and 2929,87 $\mathrm{cm}^{-1}$ howed a peak with a characteristic shape of the absorption region of $\mathrm{C}-\mathrm{H}$ Alkanes. 
The absorption area of $1610-1680 \mathrm{~cm}^{-1}$, precisely at the peak of $1639,49 \mathrm{~cm}^{-1}$, shows a typical shape representing $C=C$ alkenes. The absorption area is $1500-1600 \mathrm{~cm}-1$, menunjukkan bentuk khas ikatan $\mathrm{C}=\mathrm{C}$ aromatik. showing the typical shape of the aromatic $\mathrm{C}=\mathrm{C}$ bond. The peak of the absorption indicates the presence of aromatic cyclic bonds. The absorption area is $1050-1300 \mathrm{~cm}^{-1}$ indicating the presence of the C-O functional group, precisely at the peak of $1093,64 \mathrm{~cm}^{-1} ; 1192,01 \mathrm{~cm}^{-1}$; and $1261,45 \mathrm{~cm}^{-1}$, estimated that there is the absorption of compounds that have a $-\mathrm{OH}$ (hydroxyl) functional group, each indicating a compound of alcohol, ether, carboxylic acid, and ester groups. Aromatic rings with C-H bonds appear at absorption in the range of $690-900 \mathrm{~cm}^{-1}$, while at peaks of 40,67 $\mathrm{cm}^{-1}$ and 794,67 $\mathrm{cm}^{-1}$, they indicate the presence of aromatic cyclic bonds $[4,21,68,95]$. These results indicate the suitability of the components of simple organic compounds biodegradation products by type B1 bacteria against pyrene (Table 1).

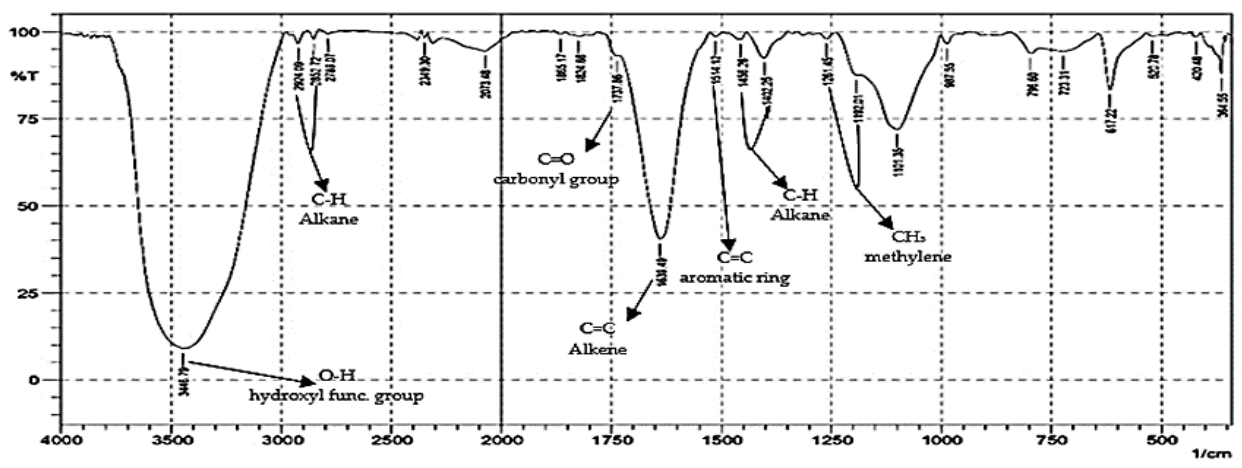

Figure 13. Spectrum showing functional groups of organic components in the biodegradation performance of Sphingobacterium sp. strain $21(\mathrm{Sb})$ against pyrene after 30 days of interaction

FTIR Spectra Analysis (Fig. 13), is absorption that shows the components of simple organic compounds, the result of pyrene biodegradation which is the performance of $\mathrm{Sb}$ bacteria. In general, it can be said that these simple organic components are the result of the decomposition of pyrene components in the form of alcohol group organic compounds. In the form of phenol, alcohol monomer, hydrogen-bonded alcohol, phenol carboxylic acid monomer, and carboxylic acid hydrogen bonds will be absorbed in about $3200-3600 \mathrm{~cm}^{-1}$, and the range $3446,79 \mathrm{~cm}^{-1}$, indicating the presence of the O-H functional group. Absorption 2924,09 $\mathrm{cm}^{-1}$ and $2852,72 \mathrm{~cm}^{-1}$, showed a typical peak shape identical to the C-H absorption region of alkanes. The absorption area of $2000 \mathrm{~cm}^{-1}$ to $1500 \mathrm{~cm}^{-1}$, precisely at $1737.86 \mathrm{~cm}^{-1}$, shows a peak with a distinctive shape, presumably the absorption area of $\mathrm{C}=\mathrm{O}$, namely aldehydes, ketones, carboxylic acids and esters. The absorption area is $1610-1680 \mathrm{~cm}^{-1}$, precisely at the peak of $1639,49 \mathrm{~cm}^{-1}$, the typical shape represents $\mathrm{C}=\mathrm{C}$ alkenes. The absorption area of $1500 \mathrm{~cm}^{-1}$ to $1600 \mathrm{~cm}^{-1}$, precisely at the peak of $1514,12 \mathrm{~cm}^{-1}$, shows a distinctive shape identical to the aromatic $\mathrm{C}=\mathrm{C}$ bond, indicating the presence of aromatic cyclic bonds. Absorption areas of $1456,26 \mathrm{~cm}^{-1}$ and $1402,25 \mathrm{~cm}^{-1}$ showed peaks with a typical shape according to the alkane $\mathrm{CH}$ absorption area, peaks of $1261,45 \mathrm{~cm}^{-1}$ and $1192,01 \mathrm{~cm}^{-1}$, or in the absorption area of $1050 \mathrm{~cm}^{-1}-1300 \mathrm{~cm}^{-1}$, indicating the methylene $\mathrm{C}-\mathrm{H}$ functional group $[38,68,96]$.

Determining and selecting the type of test bacteria that has dominant biodegradation power over other types of bacteria, which is the purpose of this research, is done by comparing all the variables that have been analyzed. Based on these variables, it is known that the bacterial isolate of Bacillus licheniformis strain ATCC 9789 (Bl), isolated from the marine sponge Auletta sp., has a relatively balanced biodegradation power against pyrene compared to bacteria of the Sphingobacterium sp. strain 21 (Sb) was isolated from seawater contaminated with PAHs [97]. Suppose the contamination of the hydrocarbon component increases, and it is predicted that it will have an impact on decreasing the quality of ground and surface water so that the availability of clean water 
will decrease [98] both in water areas (sea), land and air. In that case, it is feared that the data will contribute to increasing global warming and, in the long term, can cause climate change.

\section{Discussion}

The study of qualitative and quantitative aspects of the biodegradation performance of the two isolates ( $\mathrm{Bl}$ and $\mathrm{Sb}$ ) showed contradictory results. The qualitative analysis of the biodegradation performance of $\mathrm{Bl}$ bacteria against pyrene showed a stronger aggressiveness than Sb bacteria. It is based on the GC-MS chromatogram and the number of biodegradable components after 30 interactions which reached 10 components (Fig. 9A) and (Table 1). These results are confirmed by the FTIR spectrum, which appears to be more complex, including visible functional groups, as a manifestation of the biodegradation products in the form of simple organic compounds (Fig. 12). Qualitative analysis of the biodegradation performance of $\mathrm{Sb}$, according to the GC-MS chromatogram, identified only 6 components (Fig. 9B) and (Table 2).

Similarly, the FTIR spectrum appears simpler (Fig. 13). The results of the quantitative analysis found that the biodegradation performance of the two types of bacteria against pyrene, it appears that $\mathrm{Sb}$ bacteria are relatively stronger than $\mathrm{Bl}$ bacteria. The percentage of pyrene components that were not degraded by Bl bacteria $(61.71 \%)$ was relatively higher than that of Sb bacteria (60.00\%) (Fig. 10). It gives an interpretation that the biodegradation performance of $\mathrm{Sb}$ bacteria is relatively higher than that of $\mathrm{Bl}$ bacteria. This data is corroborated by the percentage of bacterial biodegradation performance of $\mathrm{Sb}(39.00 \%)$, slightly higher than the performance of bacteria Bl (38.29\%) (Fig. 11) on pyrene components $[3,5,11,23]$. This result is influenced by the adaptability and biodegradation mechanism that these two types of bacteria can take to the pyrene component.

The mechanism and pathway of pyrene biodegradation by bacteria based on the findings of this research according to the combination of optical data density media, biodegradation parameters, GC-MS and FTIR chromatograms, is estimated to follow the mechanism of an oxidation reaction that begins with the formation of a "cis" transition product in the form of pyrene dihydroxy nadiol, then turns into catechol. The breakup of one benzene molecule marks the pyrene structure changes into a carboxylic acid product. One $\mathrm{H}_{2} \mathrm{O}$ molecule comes out, and the pyrene structure changes to a penantroic carboxylic acid product. This process continues following the oxidation reaction process and the breakdown of the second and third rings until the final product is reached, namely a benzene carboxylic acid molecule in the form of cinnamate and a pinacol product $[27,31,39,88]$.

The illustration in Fig. 4, shows a symbiont of the marine sponge Auletta sp., a group of Bacillus bacteria, Bacillus licheniformis strain ATCC 9789 (Bl), relatively similar pathways for metabolism or pyrene biodegradation using $\mathrm{Sb}$ bacteria isolated from seawater contaminated with PAHs. In general, it can be said that the biodegradation mechanism of PAHs is thought to be similar to the biodegradation process of other types of PAHs, such as anthracene and phenanthrene. The rate of metabolism of PAHs by microorganisms depends on the number of aromatic rings. This biodegradation mechanism also has similar metabolic pathways to pyrene using Mycobacterium sp. PYR-1 [45,56,88], is through the oxidation pathway of breaking one benzene molecule so that a new molecule is formed in the form of a carboxylic compound and frees $\mathrm{H} 2 \mathrm{O}$ molecules. According to the illustration (Fig.14), it is seen that there is a limiting factor that inhibits the biodegradation process of microorganisms against PAHs components so that the biodegradation is not complete or leaves the aromatic benzene molecule. The influence of these limiting factors is thought to occur at the formation stage of carboxylic compounds, where these compounds can increase the acidity of the interactive media, which results in the potential for stopping bacterial cell division or bacterial cells experiencing mass death. Thus the biodegradation process converts carbon elements into energy through metabolic pathways, and the oxidation reaction proceeds slowly and even stops com- 
pletely $[19,23,66]$. The reaction mechanism of pyrene biodegradation by bacteria type B1 is generally illustrated in the reaction scheme according to Figure 14.

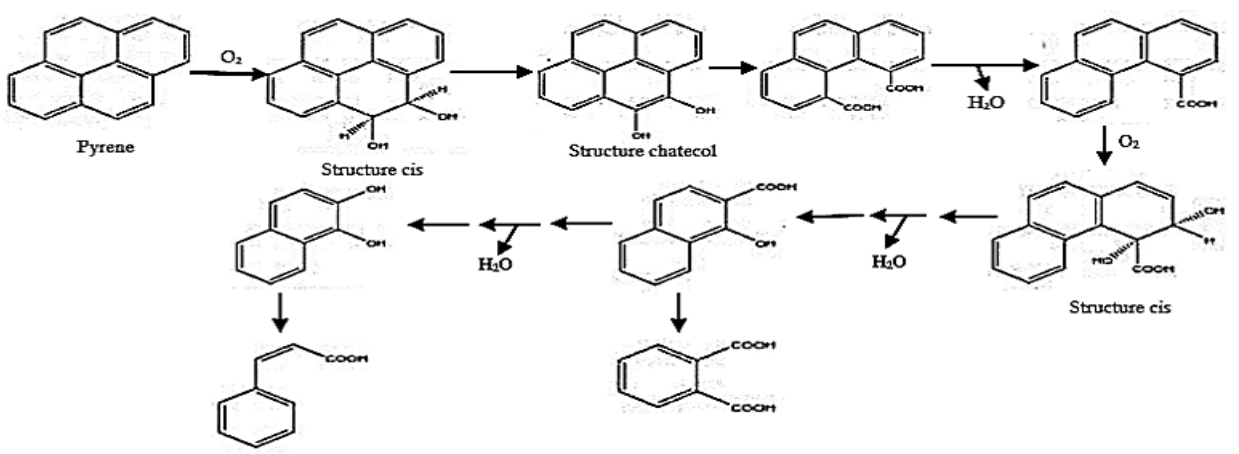

Figure 14. Illustration of pyrene biodegradation pathway by $\mathrm{Bl}$ bacteria symbiont of the marine sponge Auletta sp., the breakdown of one benzene ring forms a carboxylate after liberating an $\mathrm{H}_{2} \mathrm{O}$ molecule through the metabolic pathway of oxidation.

The results of this study are expected to be developed to screen for other types of bacteria from various sources that can biodegrade hydrocarbon components, especially PAHs [94,95]. The achievements of this research also open up opportunities for using these bacteria in the bioremediation of other types of pollutants, such as pesticide residues, heavy metals and microplastics, so that the dream of formulating crystalline carbonoclastic bacteria can be realized $[12,21,64]$. This hope is a form of environmental protection against the threat of contamination by toxic components.

\section{Conclusions}

Some of the findings obtained from this study are summarized in several conclusions: The two types of test bacteria ( $\mathrm{Bl}$ and $\mathrm{Sb}$ ) can degrade pyrene components. A qualitative study based on the number of components and FTIR spectrum showed that Bacillus licheniformis strain ATCC 9789 (Bl) had relatively stronger aggressiveness in biodegradation of pyrene than Sphingobacterium sp. strain 21 (Sb). Quantitative analysis showed that the biodegradation performance of $\mathrm{Sb}$ bacteria on pyrene components was relatively stronger than $\mathrm{Bl}$ bacteria. The total percentage of bacterial biodegradation products of $\mathrm{Sb}$ type (39.00\%) was slightly higher than that of Bl type biodegradation products (38.29\%), achieved during the interaction period of 30 days. The biodegradation products of the two test bacteria (Bl and $\mathrm{Sb}$ ) against pyrene were simple organic compounds with alcohol and carboxylic acid groups. The bio-degradation performance of the two types of bacteria tested against pyrene followed the same path, namely the carbon metabolism as an energy source through oxidation reactions.

Supplementary Materials: The following are available online at: https://www.mdpi.com/xxx/s1, Figure 1: Sampling locations of sea sponges and seawater sources of bacterial isolates; Figure 2: Isolate culture process; Figure 3: Microscopic analysis of 2 types of bacteria by Gram staining; Figure 4: The morphology of the test isolate samples; Figure 5: Bacterial cell growth curve without the addition of pyrene; Figure 6: Bacterial cell growth curve with the addition of pyrene; Figure 7-9: Peak abundance of pyrene biodegradation by bacterial isolates with interaction time of 10, 20 and 30 days, respectively; Figure 10: Percentage of pyrene that is not degraded (Using equat. 1); Figure 11: Percentage of pyrene degraded (Using equat. 2); Figure 12 and 13: FTIR spectrum of functional groups of organic components as the biodegradation performance of (Fig. 11. by Bacillus licheniformis strain ATCC 9789 and Fig. 12. by Sphingobacterium sp. strain 21; and Figure 14: Illustration of pyrene biodegradation pathway by bacteria; Table 1: Characteristics of pyrene biodegradation products by Bacillus licheniformis strain ATCC 9789; Table 2: Characteristics of pyrene biodegradation products by Sphingobacterium sp. strain 21. 


\begin{abstract}
Author Contributions: Conceptualization, I.M., R.A. and K.N.; methodology, I.M., M.P. and R.A.; software, A.A., A.R. and E.S.; validation, I.M., N.N., and I.K.; formal analysis, I.M. and S.S.; investigation, I.M., N.Nb. and H.H.; resources, E.Sn., E.H. and K.N.; data curation, I.M., K.K. and M.P.; writing-original draft preparation, I.M., K.N., R.A.; writing-review and editing, A.A., N.Nb. and E.Sn.; visualization, S.S., E.H. and E.S.; supervision, I.M., S.T. and I.K.; project administration, H.H., A.R. and A.A.; funding acquisition, I.M., N.N., S.T. and K.K All authors have read and agreed to the published version of the manuscript.
\end{abstract}

Funding: This research received external funding by the "Ministry of Research, Technology and Higher Education / National Research and Technology Agency, for granting grant funds in 2021 in the applied research scheme, according to the Master Contract number: 315/E4.1/AK.04.PT/2021", and "Number: 1868/E4/AK.04/2021, dated 07 June 2021".

Institutional Review Board Statement: This study was carried out according to the guidelines of The Committee for the Care and Use of marine biota materials approved by the Ministry of Research, Technology and Higher Education/BRIN, by the Contract number: 315/E4.1/AK.04.PT/2021.

Informed Consent Statement: Not applicable

Data Availability Statement: The data presented in this article is valid according to the results of data processing in the material supplement.

Acknowledgments: Thanks are conveyed to the Ministry of Research, Technology and Higher Education / National Research and Technology Agency, for granting grant funds in 2021 in the applied research scheme. Thanks are also conveyed to the management of the Biochemistry Laboratory, Department of Chemistry, Faculty of Mathematics and Natural Sciences, Hasanuddin University and the Microbiology Laboratory of BRPBPPP Maros, South Sulawesi, and the Forensic Laboratory of the South Sulawesi Police.

Conflicts of Interest: The authors declare no conflict of interest.

\title{
References
}

1. Abraham, N.A.; Offiong, N.A.O.; Ukafia, O.P.; Akpan, P.E. Source Apportionment of Polycyclic Aromatic Hydrocarbons (PAHs) in a Tropical Estuarine Epipelic Sediment and Its Associated Bacterial Degrading Potentials. Current Journal of Applied Science and Technology, 2018, 32(1), pp. 1-11. https://doi.org/10.9734/CJAST/2019/42891

2. Marzuk, I.; Enryani, H.; La-Nafie, N.; Dali, S. Study Biodegradation of Aromatics Pyrene Using Bacterial Isolates from the Sea and micro symbionts Sponges. Int. J. Appl. Chem., 2017, 13(3), pp. 707-720. https://doi.org/10.31227/osf.io/d38pz

3. Obire, O.; Aleruchi, O.; Wemedo, S. Fungi in Biodegradation of Polycyclic Aromatic Hydrocarbons in Oilfield Wastewater. Acta Sci Microbiol. 2020, 3(4), pp. 220-224. https://doi.org/10.31080/ASMI.2020.03.0572

4. Marzuki, I.; Asaf, R.; Paena, M.; Athirah, A.; Nisaa, K.; Ahmad, R.; Kamaruddin, M. Anthracene and Pyrene Biodegradation Performance of Marine Sponge Symbiont Bacteria Consortium. Molecules, 2021, 26(22), p. 6851. https://doi.org/10.3390/molecules26226851

5. Smułek, W.; Sydow, M.; Matejuk,Z.J.; Kaczorek, E. Bacteria involved in biodegradation of creosote PAH - A case study of long-term contaminated industrial area. Ecotoxicol Environ Saf. 2020, 187, p. 109843. https://doi.org/10.1016/j.ecoenv.2019.109843

6. Marzuki, I.; Kamaruddin, M.; Ahmad, R. Identification of marine sponges-symbiotic bacteria and their application in degrading polycyclic aromatic hydrocarbons. Biodiversitas. 2021, 22(3), pp. 1481-1488. https://doi.org/10.13057/biodiv/d220352

7. Agrawal, N.; Verma, P.; Shahi, S.K. Degradation of polycyclic aromatic hydrocarbons (phenanthrene and pyrene) by the ligninolytic fungi Ganoderma lucidum isolated from the hardwood stump. Bioresour. Bioprocess., $2018,5(1)$, p. 11. https://doi.org/10.1186/s40643-018-0197-5

8. Arroyo, A.; Provoste, F.; Rodríguez, M.; Prieto, A.L. A mechanistic model to assess the fate of naphthalene and benzo(A)pyrene in a chilean wwtp. Processes. 2021, 9(8), p. 1313. https://doi.org/10.3390/pr9081313

9. Marzuki, I.; Chaerul, M.; Erniati, E.; Asmeati, A.; Paserangi, I. Biodegradation of aliphatic waste components of oil sludge used micro symbiont of Sponge Niphates sp. ICMS, IOP Conf. Series: Eart E Environ. Sci., 2020, 429(1). p. 012056. https://doi.org/10.1088/1755-1315/429/1/012056

10. Shehu, U.; Ahmad, F.A.; Yusuf, F.; Muhammad, F.; Yakasai, H.M. Isolation and Identification of Anthracene Utilizing Proteus vulgaris from Oil Spill Contaminated Soil at NNPC Depot Kano State Nigeria. J. Adv. Biol. Biotechnol. 2019, 24(10), pp. 46-53. https://doi.org/10.9734/jabb/2021/v24i1030246

11. Pandey, P.; Kapley, A.; Brar, S.K. Editorial: Biodegradation of High Molecular Weight Polyaromatic Hydrocarbons in Different Environments. Front. Microbiol., 2021, 12(July), pp. 2020-2022. https://doi.org/10.3389/fmicb.2021.704897 
12. Marzuki, I.; Pratama, I.; Ismail, H.E.; Paserangi, I.; Kamaruddin, M.; Chaerul, M.; Ahmad, R. The Identification and Distribution Components of Polycyclic Aromatic Hydrocarbon Contaminants at the Port of Paotere , Makassar, South Sulawesi. IOP Conf. Series: Earth and Env. Sci. 2021, 679, p. 012017. https://doi.org/10.1088/1755-1315/679/1/012017

13. Nzila, A. Current status of the degradation of aliphatic and aromatic petroleum hydrocarbons by thermophilic microbes and future perspectives. Int. J. Environ. Res. Public Health, 2018, 15(12), pp. 1-23. https://doi.org/10.3390/ijerph15122782

14. Lu, C.; Hong, Y.; Liu, J.; Gao, Y.; Ma, Z.; Yang B.; Ling, W.; Waigi, M.G. A PAH-degrading bacterial community enriched with contaminated agricultural soil and its utility for microbial bioremediation. Environmental Pollution, 2019, 251, pp. 773-782. https://doi.org/10.1016/j.envpol.2019.05.044

15. Mao, J.; Guan, W. Fungal degradation of polycyclic aromatic hydrocarbons (PAHs) by Scopulariopsis brevicaulis and its application in bioremediation of PAH-contaminated soil. Acta Agric. Scand. Sect. B Soil Plant Sci., 2016, 66(5), pp. $399-405$. https://doi.org/10.1080/09064710.2015.1137629

16. Al-Hawash, A.B.; Dragh, M.A.; Li. S.; Alhujaily, A.; Abbood, H.A.; Zhang, X.; Ma, F. Principles of microbial degradation of petroleum hydrocarbons in the environment. Egypt. J. Aquat. Res., 2018, 44(2), pp. 71-76. https://doi.org/10.1016/j.ejar.2018.06.001

17. Bendouz, M.; Dionne, D.; Tran, L.H.; Coudert, L.; Mercier, G.; Blais, J.F. Polycyclic Aromatic Hydrocarbon Oxidation from Concentrates Issued from an Attrition Process of Polluted Soil Using the Fenton Reagent and Permanganate. Water, Air, and Soil Pollution. 2017, 228, p. 115. https://doi.org/10.1007/s11270-017-3292-x

18. Bezza, F.A.; Chirwa, E.M.N. Biosurfactant-enhanced bioremediation of aged polycyclic aromatic hydrocarbons (PAHs) in creosote contaminated soil Fisseha. Chemosphere. 2016, 144, pp. 635-644. https://doi.org/10.1016/j.chemosphere.2015.08.027; P.Mid: 26408261

19. Marzuki, I.; Daris, L.; Yunus, S.; Riana, A.D. Selection and characterization of potential bacteria for polycyclic aromatic biodegradation of hydrocarbons in sea sponges from Spermonde Islands, Indonesia. AACL Bioflux. 2020, 13(6), pp. 3493-3506.

20. Lasota, J.; Łyszczarz, Y.; Kempf, P.; Kempf, M.; Błońska, E. Effect of Species Composition on Polycyclic Aromatic Hydrocarbon (PAH) Accumulation in Urban Forest Soils of Krakow. Water. Air. Soil Pollut., 2021, 232(2), p. 74. https://doi.org/10.1007/s11270-021-05043-0

21. Marzuki, I.; Nisaa, K.; Asaf, R.; Armus, R.; Kamaruddin, M.; Sapar, A.; Emelda, A. Biodegradation mechanism of naphthalene using marine sponge symbiotic bacteria. IOP Conf. Ser. Earth Environ. Sci., 2021, 890, p. 012020. https://doi.org/10.1088/1755-1315/890/1/012020

22. Arjuna, A.; Olson, M.T.; Tokman, S.; Walia, R.; Mohanakumar, T.; Hashimi, A.Samad.; Smith, M.A.; Bremner, R.M.; Omar, A.; Norton, N. Antibody-Mediated Rejection and Sponge Effect in a Redo Lung Transplant Recipient. Case Rep Transplant. 2021, ID 6637154, pp. 1-4. https://doi.org/10.1155/2021/6637154; P.Mid: 34221532; P.M.Cid: PMC8213496

23. Armus, R.; Selry, C.; Marzuki, I.; Hasan, H.; Syamsia, S.; Sapar, A. Investigation of Potential Marine Bacterial Isolates in Biodegradation Methods on Hydrocarbon Contamination. J. of Physics: Conference Series, 2021, 1899(1), p. 012006. https://doi.org/10.1088/1742-6596/1899/1/012006

24. Dutta, K.; Shityakov, S. New Trends in Bioremediation Technologies Toward Environment-Friendly Society: A Mini-Review. Front. Bioeng. Biotechnol., 2021, 9(August), p. 666858. https://doi.org/10.3389/fbioe.2021.666858

25. Galitskaya, P.; Biktasheva, L.; Blagodatsky, S.; Selivanovskaya, S. Response of bacterial and fungal communities to high petroleum pollution in different soils. Sci. Rep., 2021, 11(1), pp. 1-18. https://doi.org/10.1038/s41598-020-80631-4

26. Knobloch, S.; Jóhannsson, R.; Marteinsson, V. Bacterial diversity in the marine sponge Halichondria panicea from Icelandic waters and host-specificity of its dominant symbiont "candidatus Halichondribacter symbioticus. FEMS Microbiology Ecology, 2018, 95(1), pp. 1-13. https://doi.org/10.1093/femsec/fiy220

27. Kim, H.-W.; Jo, J.H.; Kim, Ye.-B,; Le, T.K.; Cho, C.-W.; Yun, C.-H.; Chi, W.S.; Yeom, S.-J. et al.. Biodegradation of polystyrene by bacteria from the soil in common environments. J. Hazard. Mater., 2021, 416(August), p. 126239. https://doi.org/10.1016/j.jhazmat.2021.126239

28. awniczak, T.; Woźniak-Karczewska, M.; Loibner, A.P.; Heipieper, H.J.; Chrzanowski, T. Microbial degradation of hydrocarbons-basic principles for bioremediation: A review. Molecules, 2020, 25(4), pp. 1-19. https://doi.org/10.3390/molecules25040856

29. Marzuki, I.; Noor, A.; La-Nafie, N.; Djide, M. N. Sponge Role In Alleviating Oil Pollution Through Sludge Reduction, A Preliminary Approach. Int. Journal of App. Chem., 2015, 11(4), pp. 427-441. https://doi.10.17605/OSF.IO/S9HTG

30. Nikel, P.I.; Silva-Rocha, R.; Benedetti, I.; De-Lorenzo, V. The private life of environmental bacteria: Pollutant biodegradation at the single cell level. Environmental Microbiology, 2014, 16(3), pp. 628-642. https://doi.org/10.1111/1462-2920.12360

31. Al-Dhabaan, F.A. Morphological, biochemical and molecular identification of petroleum hydrocarbons biodegradation bacteria isolated from oil polluted soil in Dhahran, Saud Arabia. Saudi J Biol Sci. 2019, 26(6), pp. 1247-1252. https://doi.org/10.1016/j.sjbs.2018.05.029; P.Mid:.31516354; P.M.Cid: PMC6733695

32. Al-Nasrawi, H. Role of Fungi in Bioremediation. Adv. Biotechnol. Microbiol., 2019, 12(4), pp. 77-81. https://doi.org/10.19080/AIBM.2019.12.555841

33. Bisht, S.; Pandey, P.; Bhargava, B.; Sharma, S.; Kumar, V,; Krishan, D. Bioremediation of polyaromatic hydrocarbons (PAHs) using rhizosphere technology. Brazilian J. Microbiol., 2015, 46(1), pp. 7-21. https://doi.org/10.1590/S1517-838246120131354 
34. Bodor, A.; Bounedjouma, N.; Feigl, G.; Duzs, A.; Laczi, K.; Szilágyi, A.; Rákhely, G.; Perei, K. Exploitation of extracellular organic matter from Micrococcus luteus to enhance ex situ bioremediation of soils polluted with used lubricants. J. Hazard. Mater., 2021, 417, p. 125996. https://doi.org/10.1016/i.jhazmat.2021.125996

35. Brzeszcz, J.; Kaszycki, P. Aerobic bacteria degrading both n-alkanes and aromatic hydrocarbons: an undervalued strategy for metabolic diversity and flexibility. Biodegradation, 2018, 29(4), pp. 359-407. https://doi.org/10.1007/s10532-018-9837-x

36. Cao, H.; Wang, C.; Liu, H.; Jia, W.; Sun, H. Enzyme activities during Benzo[a]pyrene degradation by the fungus Lasiodiplodia theobromae isolated from a polluted soil. Sci. Rep., 2020, 10(1), pp. 1-11. https://doi.org/10.1038/s41598-020-57692-6

37. Chulalaksananukul, S.; Gadd, G.M.; Sangvanich, P.; Sihanonth, P.; Piapukiew, J.; Vangnai, A.S. Biodegradation of benzo(a)pyrene by a newly isolated Fusarium sp. FEMS Microbiol. Lett., 2006, 262(1), pp. 99-106. https://doi.org/10.1111/j.1574-6968.2006.00375.x

38. Fang, H.; Shi, Y.; Zhou, M.; Niu, Q. Influence of n-Hexadecane and Naphthalene on Anaerobic Digestion: Kinetic Simulation, DOM Variation and Microbial Community Assessment. GEESD, IOP, Conf. Series: Earth and Environmental Science, 2020, 555, p. 012038. https://doi.org/10.1088/1755-1315/555/1/012038

39. Fu, X.; Wang, H.; Bai, Y.; Xue, J.; Gao, Y.; Hu, S.; Wu, T.; Sum, J. Systematic degradation mechanism and pathways analysis of the immobilized bacteria: Permeability and biodegradation, kinetic and molecular simulation. Environ Sci Ecotechnology. 2020, 2,p. 100028. https://doi.org/10.1016/j.ese.2020.100028

40. Govarthanan, M.; Fuzisawa, S.; Hosogai, T,; Chang, Y.C. Biodegradation of aliphatic and aromatic hydrocarbons using the filamentous fungus Penicillium sp. CHY-2 and characterization of its manganese peroxidase activity. RSC Adv., 2017, 7(34), pp. 20716-23. https://doi.org/10.1039/C6RA28687A

41. Guo, J.; Wen, X. Performance and kinetics of benzo(a)pyrene biodegradation in contaminated water and soil and improvement of soil properties by biosurfactant amendment. Ecotoxicol Environ Saf. 2021, 207, p. 111292. https://doi.org/10.1016/j.ecoenv.2020.111292; P.Mid: 32919193

42. Hunting, E.R.; Van Soest, R.W.M.; Van Der Geest, H.G.; Vos, A.; Debrot, A.O. Diversity and spatial heterogeneity of mangrove associated sponges of Curaçao and Aruba. Contrib. to Zool., 2008, 77(4), pp. $205-215$. https://doi.org/10.1163/18759866-07704001

43. Ja' nczuk, B.; Szymczyk, K.; Zdziennicka, A. Adsorption Properties of Hydrocarbon and Fluorocarbon Surfactants Ternary Mixture at the Water-Air Interface. Molecules, 2021, 26, p. 4313. https://doi.org/10.3390/molecules26144313; P.Mid: 34299588 P.M.Cid: PMC8304021

44. Kui-Ma, X.; ling-Wu, L.; Fam, H. Heavy metal ions affecting the removal of polycyclic aromatic hydrocarbons by fungi with heavy-metal resistance. Appl. Microbiol. Biotechnol., 2014, 98(23), pp. pp. 9817-27. https://doi.org/10.1007/s00253-014-5905-2

45. Laothamteep, N.; Kawano, H.; Vejarano, F.; Minakuchi, C.S.; Shintani, M.; Nojiri, H.; Pinyakong, O. Effects of environmental factors and coexisting substrates on PAH degradation and transcriptomic responses of the defined bacterial consortium OPK. Environ Pollut. 2021, 277, p. 116769. https://doi.org/10.1016/j.envpol.2021.116769; P.Mid: 33676341

46. Marzuki, I.; Daris, L.; Nisaa, K.; Emelda, A. The power of biodegradation and bio-adsorption of bacteria symbiont sponges sea on waste contaminated of polycyclic aromatic hydrocarbons and heavy metals. IOP Conf. Series: Earth and Env. Sci, 2020, 584, p. 012013. https://doi.org/10.1088/1755-1315/584/1/012013

47. Medi', A.; Lješević, M.; Inui, H.; Stojanovi', K.; Karad`zi', I.; Be`skoski,d, V.; Koji, I. Efficient biodegradation of petroleum: $\mathrm{N}$-alkanes and polycyclic aromatic hydrocarbons by polyextremophilic Pseudomonas aeruginosa san ai with multidegradative capacity. RSC Adv. 2020, 10(24), pp. 14060-70. https://doi.org/10.1039/C9RA10371F

48. Liu, S.H.; Zeng, G.-M.; Niu, Q.-Y.; Liu, Y.; Zhou, L.; Jiang, L.-H.; Tang, Z.-F.; Xu, P.; Zhang, C,; Cheng, M. Bioremediation mechanisms of combined pollution of PAHs and heavy metals by bacteria and fungi: A mini review. Bioresour. Technol., 2017, 224, pp. 25-33. https://doi.org/10.1016/j.biortech.2016.11.095

49. Marzuki, I.; Ahmad, R.; Kamaruddin, M.; Asaf, R.; Armus, R.; Siswanty, I. Performance of cultured marine sponges-symbiotic bacteria as a heavy metal bio-adsorption. Biodiversitas, 2021, 22(12), pp. 5536-5543. https://doi.org/10.13057/biodiv/d220352

50. Liu, X.-X.; Hu, X.; Cao, Y.; Pang, W.-j.; Huang, J.-y.; Guo, P.; Huang, L. Biodegradation of Phenanthrene and Heavy Metal Removal by Acid-Tolerant Burkholderia fungorum FM-2. Front. Microbiol., 2019, 10(Mar), pp. 1-13. https://doi.org/10.3389/fmicb.2019.00408

51. Li, Q.; Liu, J.; Gadd, G.M. Fungal bioremediation of soil co-contaminated with petroleum hydrocarbons and toxic metals. Appl. Microbiol. Biotechnol., 2020, 104(21), pp. 8999-9008. https://doi.org/10.1007/s00253-020-10854-y

52. Marzuki, I.; Alwi, R.S.; Erniati, E.; Kamaruddin, M.; Sinardi, S.; Iryani, A.S. Chitosan Performance of Shrimp Shells in The Biosorption Ion Metal of Cadmium, Lead and Nickel Based on Variations pH Interaction. Atlantik Press, 2020, 165, pp. 6-11. https://doi.org/10.31219/osf.io/kmr5h

53. Bibi, F.; Faheem, M.; Azhar, E.I.; Yasir, M.; Alvi, S.A.; Kamal, M.A., ... Naseer, M.I. Bacteria From Marine Sponges: a Source of New Drugs. Current Drug Metabolism, 2016, 18(May), pp. 11-15. https://doi.org/10.2174/1389200217666161013090610 
54. Bart, M.C.; Hudspith, M.; Rapp, H.T.; Verdonschot, P.F.M.; de Goeij, J.M. A Deep-Sea Sponge Loop? Sponges Transfer Dissolved and Particulate Organic Carbon and Nitrogen to Associated Fauna. Front Mar Sci. 2021, 8, pp. 1-12. https://doi.org/10.3389/fmars.2021.604879

55. Lavy, A.; Keren, R.; Haber, M.; Schwartz, I.; Ilan, M. Implementing sponge physiological and genomic information to enhance the diversity of its culturable associated bacteria. FEMS Microbiol Ecol. 2014, 87(2), pp. 486-502. https://doi.org/10.1111/1574-6941.12240; P.Mid: 24164535

56. Nedoroda, V.; Trokhymenko, G.; Khrapko, T.; Koliehova, A. Analysis of Petroleum Biodegradation by a Bacterial Consortium of Bacillus amyloliquefaciens ssp. Plantarum and Bacillus subtilis. J. Ecol. Eng., 2021, $22(11)$, pp. 36-42. https://doi.org/10.12911/22998993/143017

57. Spini, G.; Spina, F.; Poli, A.; Blieux, A,-L.; Regnier, T.; Gramellini, C.; Varese, G.C.; Puglisi, E. Molecular and Microbiological Insights on the Enrichment Procedures for the Isolation of Petroleum Degrading Bacteria and Fungi. Front. Microbiol., 2018, 9(Oct.), p. 2543. https://doi.org/10.3389/fmicb.2018.02543

58. Yetti, E.; Thontowi, A.; Yopi, Y.; Lisdiyanti, P. Screening of Marine bacteria capable of degrading various polyaromatic hydrocarbons. Squalen Bull Mar Fish Postharvest Biotechnol. 2015, 10(3), pp. $121-127$. https://doi.org/10.15578/squalen.v10i3.123

59. Yogaswara, D. Concentrations of PAHs ( Polycyclicaromatic Hydrocarbons ) Pollutant in Sediment of The Banten Bay. Bulletin of The Marine Geology, 2017, 32(2), pp. 61-66. https://doi.org/10.32693/bomg.32.2.2017.377

60. Souza, H.M.de-L.; Barreto, L.R.; da Mota, A.J.; de Oliveira, L.A.; Barroso, H.dos-S.; Zanotto, S.P. Tolerance to polycyclic aromatic hydrocarbons (PAHs) by filamentous fungi isolated from contaminated sediment in the Amazon region. Acta Sci. - Biol. Sci., 2017, 39(4), pp. 481-488. https://doi.org/10.4025/actascibiolsci.v39i4.34709

61. Saraswathy, A.; Hallberg, R. Degradation of pyrene by indigenous fungi from a former gasworks site. FEMS Microbiol. Lett., 2002, 210(2), pp. 227-232. https://doi.org/10.1111/j.1574-6968.2002.tb11185.x

62. Marzuki, I.; Sinardi, S.; Pratama, I.; Chaerul, M.; Paserangi, I.; Kamaruddin, M.; Asaf, R. Performance of sea sponges micro symbionts as a biomaterial in biodegradation naphthalene waste of modified. IOP Conf. Series: Earth and Env. Sci. 2021, 737, p. 012016. https://doi.org/10.1088/1755-1315/737/1/012016

63. Fomina, M.; Charnock, J.M.; Hillier, S.; Alvarez, R.; Livens, F.; Gadd, G.M. Role of fungi in the biogeochemical fate of depleted uranium. Curr. Biol., 2008, 18(9), pp. 375-377. https://doi.org/10.1016/j.cub.2008.03.011

64. Medaura, M.C.; Guivernau, M.; Moreno-Ventas, X.; Prenafeta-Boldú, F.X.; Viñas, M. Bioaugmentation of Native Fungi, an Efficient Strategy for the Bioremediation of an Aged Industrially Polluted Soil With Heavy Hydrocarbons. Front. Microbiol., 2021, 12(March), pp. 1-18. https://doi.org/10.3389/fmicb.2021.626436

65. Dadrasnia, A.; Usman, M.M.; Lim, K.T.; Farahiyah, F.H.; Rodzhan, N.Sb.M.; Karim, S.H.A.; Ismail, S. Bio-Enhancement of Petroleum Hydrocarbon Polluted Soil Using Newly Isolated Bacteria. Polycyclic Aromatic Compounds, 2020, 40, pp. $484-493$. https://doi.org/10.1080/10406638.2018.1454966

66. Marzuki, I.; Ali, M.Y.; Syarif, H.U.; Gusty, S.; Ritnawati, R.; Daris, L.; Nisaa, K. Investigation of Biodegradable Bacteria as Bio indicators of the Presence of PAHs Contaminants in Marine Waters in the Marine Tourism Area of Makassar City. IOP Conf. Series: Eart Environ. Sci., 2021, 750, p. 012006. https://doi.org/10.1088/1755-1315/750/1/012006

67. Elenga-Wilson, P.S.; Kayath, C.A.; Mokemiabeka, N.S.; Nzaou, S.A.E.; Nguimbi, E.; Ahombo, G. Profiling of Indigenous Biosurfactant-Producing Bacillus Isolates in the Bioremediation of Soil Contaminated by Petroleum Products and Olive Oil. Int. J. Microbiol. Hindawi, 2021, 221, p. 9565930. https://doi.org/10.1155/2021/9565930

68. Keller-Costa, T.; Jousset, A.; Van-Overbeek, L.; Van-Elsas, J. D.; Costa, R. The freshwater sponge Ephydatia fluviatilis harbours diverse Pseudomonas species (Gammaproteobacteria, Pseudomonadales) with broad-spectrum antimicrobial activity. PLoS ONE, 2018, 9(2). https://doi.org/10.1371/journal.pone.0088429

69. Liu, W.J.; Duan, X.D.; Wu, L.P.; Masakorala, K. Biosurfactant Production by Pseudomonas aeruginosa SNP0614 and its Effect on Biodegradation of Petroleum. Applied Biochemistry and Microbiology, 2018, 54(2), 155-162. https://doi.org/10.1134/S0003683818020060

70. Yang, J.; Sun, J.; Lee, O.O.; Yim, H.M.; Qian, P.Y. Phylogenetic diversity and community structure of sponge-associated bacteria from mangroves of the Caribbean Sea. Aquat. Microb. Ecol., 2011, 62(3), pp. $231-240$. https://doi.org/10.3354/ame01473

71. Okoro, C.C. Biosurfactant-enhanced remediation of hydrocarbon contaminated mangrove swamp. Nature and Science, 2010, 8(8), pp. 152-162. https://doi.10.4314/ijbcs.v3i1.42736

72. Isikhuemhen, O.S.; Mikiashvili, N.A.; Senwo, Z.N.; Ohimain, E.I. Biodegradation and Sugar Release from Canola Plant Biomass by Selected White Rot Fungi. Advances in Biological Chemistry, 2014, 04(06), pp. $395-406$. https://doi.org/10.4236/abc.2014.46045

73. Ray, M.; Kumar, V.; Banerjee, C.; Gupta, P.; Singh, S.; Singh, A. Investigation of biosurfactants produced by three indigenous bacterial strains, their growth kinetics and their anthracene and fluorene tolerance. Ecotoxicol Environ Saf. 2021, 208, p. 111621. https://doi.org/10.1016/j.ecoenv.2020.111621; P.Mid: 33396141

74. Miao, L.L.; Qu, J.; Liu, Z.P. Hydroxylation at Multiple Positions Initiated the Biodegradation of Indeno[1,2,3-cd]Pyrene in Rhodococcus aetherivorans IcdP1. Front Microbiol. 2020, 11, pp. 1-13. https://doi.org/10.3389/fmicb.2020.568381; P.Mid: 33072027; P.M.Cid: PMC7536264 
75. Hou, L.; Majumder, E.L.W. Potential for and distribution of enzymatic biodegradation of polystyrene by environmental microorganisms. Materials (Basel)., 2021, 14(3), pp. 1-20. https://doi.org/10.3390/ma14030503

76. Khabouchi, I.; Khadhar, S.; Chaouachi, D.; Chekirbene, A.; Doumenq, P. Study of organic pollution in superficial sediments of Meliane river catchment area : aliphatic and polycyclic aromatic hydrocarbons Study of organic pollution in superficial sediments of Meliane river catchment area: aliphatic and polycyclic aromatic hyd. Enviroment Monit Assess. 2020, April, pp. 282-290. https://doi.org/10.1007/s10661-020-8213-6; P.Mid: 32285216

77. Onwosia, C.O.; Odibob, F.-J.K.; Enebechia, C.K.; Nwankwegub, A.S.; Ikeleb, A.I.; Okehc, O.C. Soil and Sediment Contamination: An International Bioremediation of Diesel-contaminated Soil by Composting with Locally Generated Bulking Agents Bioremediation of Diesel-contaminated. Soil Sediment Contam. 2017, 0(0), pp. 1-19. https://doi.org/10.108015320383.2017.1348337

78. Marzuki, I.; Gusty, S.; Armus, R.; Sapar, A.; Asaf, R.; Athirah, A.; Jaya, A. Secondary Metabolite Analysis and Anti-Bacteria and Fungal Activities of Marine Sponge Methanol Extract Based on Coral Cover. In The 6th Int. Conf. on Basic Sciences (IAP Conf. Proc.), 2021, 2360, p.040007 https://doi.org/10.1063/5.0059500

79. Roy, A.; Sar, P.; Sarkar, J.; Dutta, A.; Sarkar, P.; Gupta, A.; Mohapatra, B.; Pal, S.; Kazy, S.K. Petroleum hydrocarbon rich oil refinery sludge of North-East India Harbours anaerobic, fermentative, sulfate-reducing, syntrophic and methanogenic microbial populations. BMC Microbiol., 2018, 18(1), pp. 1-22. https://doi.org/10.1186/s12866-018-1275-8

80. Kamaruddin, M.; Marzuki, I.; Burhan, A.; Ahmad, R. Screening acetylcholinesterase inhibitors from marine-derived actinomycetes by simple chromatography. The 1st Int. Conf. on Biotech.and Food Sciences IOP Conf. Series: Earth and Env. Sci., 2021, 679, p. 012011. https://doi.org/10.1088/1755-1315/679/1/012011

81. Košnář, Z.; Částková, T.; Wiesnerová, L.; Praus, L.; Jablonský, I.; Koudela, M.; Tlustoš, P. Comparing the removal of polycyclic aromatic hydrocarbons in soil after different bioremediation approaches in relation to the extracellular enzyme activities. J Environ Sci. 2018, XX, pp. 1-10. https://doi.org/10.1016/j.jes.2018.05.007; P.Mid: 30528015

82. Parhamfar, M.; Abtahia, H.; Godinib, K.; Saeedi, R.; Sartaje, M.; Villaseñorf, J.; Coulong, F.; Kumarg, V.; Soltanighiash, T.; Radi, E.G.; Koolivand, A. Biodegradation of heavy oily sludge by a two-step inoculation composting process using synergistic effect of indigenous isolated bacteria. Process Biochem., 2020, 91, pp. $223-230$. https://doi.org/10.1016/j.procbio.2019.12.014

83. White, J.R.; Patel, J.; Ottesen, A.; Arce, G.; Blackwelder, P.; Lopez, J.V. Pyrosequencing of Bacterial Symbionts within Axinella corrugata Sponges: Diversity and Seasonal Variability. Plos One, 2012, 7(6), pp. 1-12. https://doi.org/10.1371/journal.pone.0038204

84. Selvin, J.; Shanmugha Priya, S.; Seghal-Kiran, G.; Thangavelu, T.; Sapna-Bai, N. Sponge-associated marine bacteria as indicators of heavy metal pollution. Microbiol. Res., 2009, 164(3), pp. 352-363. https://doi.org/10.1016/j.micres.2007.05.005

85. Marzuki, I.; Noor, A.; La-Nafie, N.; Djide, M.N. Moleculer Characterization Of Gene 16S rRNA Microsymbionts In Sponge At Melawai Beach, East Kalimantan. Mar. Chim. Acta, 2015, 16(1), pp. 38-46. https://doi.10.31219/osf.io/xkp9b

86. Morganti, T.M.; Ribes, M.; Yahel, G.; Coma, R. Size Is the Major Determinant of Pumping Rates in Marine Sponges. Front Physiol. 2019, 10, p. 1474. https://doi.org/10.3389/fphys.2019.01474; P.Mid: 31920688; P.M.Cid: PMC6917621

87. Orani, A.M.; Barats, A.; Vassileva, E.; Thomas, O.P. Marine sponges as a powerful tool for trace elements biomonitoring studies in coastal environment. Mar Pollut Bull. 2018, 131, pp. 633-645. https://doi.org/10.1016/j.marpolbul.2018.04.073; P.Mid: 29886991

88. Lundstedt, S. Analysis of PAHs and their transformation products in contaminated soil and remedial processes. Netherlands: Akademisk avhandling Som, Department of Env. and Toxicological Chemistry, 2003, University of Amsterdam. http://urn.kb.se/resolve?urn=urn:nbn:se:umu:diva-57</div $>$

89. Yu, Y.; Zhang, Y.; Zhao, N.; Guo, J.; Xu, W.; Ma, M.; Li, X. Remediation of crude oil-polluted soil by the bacterial rhizosphere community of suaeda salsa revealed by 16S rRNA genes. Int. J. Environ. Res. Public Health, 2020, 17(5), pp. 1-18. https://doi.org/10.3390/ijerph17051471

90. Gusty, S.; Tumpu, M.; Parung, H.; Marzuki, I. Marshall Characteristics of Porous Asphalt Containing Low Density Polyethylene (LDPE) Plastic Waste. IOP Conf. Ser. Earth Environ. Sci., 2021, 921, p. 012025. https://doi.org/10.1088/1755-1315/921/1/012025

91. Xia, Y.; Li, A.D.; Deng, Y.; Jiang, X.T.; Li, L.G.; Zhang, T. Min ION Nanopore sequencing enables correlation between resistome phenotype and genotype of coliform bacteria in municipal sewage. Frontiers in Microbiology, 2017, 8(Oct.), pp. 1-13. https://doi.org/10.3389/fmicb.2017.02105

92. Ramdass, A.C.; Rampersad, S.N. Diversity and oil degradation potential of culturable microbes isolated from chronically contaminated soils in Trinidad. Microorganisms J., 2021, 9(6), p. 1167. https://doi.org/10.3390/microorganisms9061167

93. Su, X.M.; Bamba, A.M.; Zhang, S.; Zhang, Y.G.; Hashmi, M.Z.; Lin, H.J.; Ding, L.X. Revealing potential functions of VBNC bacteria in polycyclic aromatic hydrocarbons biodegradation. Lett Appl Microbiol. 2018, 66(4), pp. $277-283$. https://doi.org/10.1111/lam.12853; P.Mid: 29350767

94. Sahu, L. Presence of Hydrocarbon Degrading Bacteria in Contaminated Soil Collected From Various Fuel Station in Bhilai, Chhattisgarh. Int. J. Res. Appl. Sci. Eng. Technol., 2021, 9(11), pp. 1802-1804. https://doi.org/10.22214/ijraset.2021.39107

95. Akinde, S.B.; Iwuozor, C.C. Alkane Degradative Potentials of Bacteria Isolated From the Deep Atlantic Ocean of the Gulf of Guinea. J. of Bioremediation and Biodegradation, 2012, 03(1), pp. 1-6. https://doi.org/10.4172/2155-6199.1000135 
96. Zhang, B.; Zhang, L.; Zhang, X. Bioremediation of petroleum hydrocarbon-contaminated soil by petroleum-degrading bacteria immobilized on biochar. RSC Adv., 2019, 9(60), pp. 35304-311. https://doi.org/10.1039/C9RA06726D

97. Chaerul, M.; Gusty, S.; Marzuki, I.; Nur, N.K. Potential impact of climate change on water resources availability in Bantaeng District, South Sulawesi Province. Annual Conf. on Computer Sci. and Engineering Tech. (AC2SET) IOP Conf. Series: Earth E Environ. Sci, 2021, 1088, p. 012109. https://doi.org/10.1088/1757-899X/1088/1/012109

98. Rusli, M.; Chaerul, M.; Marzuki, I. Adaptation of Climate Change to Vulnerability of Raw Water Availability in Bantaeng, South Sulawesi. J. Phys. Conf. Ser., 2021, 1899, p. 012062. https://doi.org/10.1088/1742-6596/1899/1/012062 